\title{
ETHzürich
}

ETH Library

\section{The youngest basic oceanic magmatism in the Alps (Late Cretaceous; Chiavenna unit, Central Alps) \\ Geochronological constraints and geodynamic significance}

\section{Journal Article}

\section{Author(s):}

Liati, Anthi; Gebauer, Dieter; Fanning, C. Mark

Publication date:

2003-11

\section{Permanent link:}

https://doi.org/10.3929/ethz-b-000052993

\section{Rights / license:}

In Copyright - Non-Commercial Use Permitted

\section{Originally published in:}

Contributions to Mineralogy and Petrology 146(2), https://doi.org/10.1007/s00410-003-0485-7 


\section{The youngest basic oceanic magmatism in the Alps (Late Cretaceous; Chiavenna unit, Central Alps): geochronological constraints and geodynamic significance}

Received: 20 January 2003 / Accepted: 12 May 2003/Published online: 10 September 2003

(C) Springer-Verlag 2003

\begin{abstract}
Cathodoluminescence-controlled radiometric dating (U-Pb SHRIMP) was carried out on zircon domains from metabasic rocks of the Chiavenna unit, a major mafic/ultramafic-bearing unit in the Central Alps. Co-magmatic zircon domains from amphibolites near Chiavenna and Prata areas yielded weighted mean ${ }^{206} \mathrm{~Pb} /{ }^{238} \mathrm{U}$ ages at $93.0 \pm 2.0$ and $93.9 \pm 1.8 \mathrm{Ma}$, respectively, interpreted as the age of crystallization of the magmatic protoliths. These ages fit well with the time of late spreading in the Valais Ocean, as suggested by previous paleogeographic reconstructions. Inherited zircon grains and/or core domains (Permo-Triassic, Carboniferous, Proterozoic) are abundant, indicating proximity of the Chiavenna unit to thinned continental crust. This is in line with the origin of this unit from subcontinental mantle sources, as suggested previously on petrological and structural grounds. Metamorphic zircon domains from one amphibolite near Chiavenna yielded a weighted mean ${ }^{206} \mathrm{~Pb} /{ }^{238} \mathrm{U}$ age at $37.1 \pm 0.9 \mathrm{Ma}$, identical to the $38.5 \pm 0.9 \mathrm{Ma}$ SHRIMP age of an amphibolitized eclogite of the Antrona ophiolites (Valais domain, Western Alps). Precise metamorphic ages were difficult to obtain from the composite (poly)metamorphic rim domains of the Prata amphibolite. This is attributed to the location of the Prata area close to the granulite-facies Gruf unit (metamorphosed at ca. $33 \mathrm{Ma}$ ) and to the 24-25 Ma old Novate granite, where metamorphic/fluid events probably caused multiple resetting to various degrees. The ca. 93 Ma old
\end{abstract}

Editorial responsibility: W. Schreyer

\footnotetext{
A. Liati $(\square) \cdot$ D. Gebauer

Institute of Isotope Geology and Mineral Resources,

Swiss Federal Institute of Technology (ETH),

Sonneggstrasse 5,

8092 Zurich, Switzerland

E-mail: liati@erdw.ethz.ch

C. M. Fanning

Research School of Earth Sciences,

The Australian National University, Mills Road,

Canberra, ACT 0200, Australia
}

magmatism, identified for the first time in the Chiavenna unit, is the youngest basic oceanic magmatism reported in the Alps. The $37.1 \pm 0.9 \mathrm{Ma}$ old metamorphism in the Chiavenna unit, attributed to the Valais domain, confirms the model suggesting stepwise younging of metamorphic ages from the south (Adriatic plate) to the north (European plate). It is older than metamorphism in the European margin (ca. 35-31 Ma) lying to the north of the Valais domain and younger than that in the Piemont-Ligurian Ocean (ca. 44-45 Ma) lying to the south of the Valais domain.

\section{Introduction}

Multidisciplinary studies of ophiolitic, mafic/ultramafic rock associations in the Alps suggest the former existence of at least two oceans, originally located between Europe and Africa (Adria): (1) the Piemont-Ligurian Ocean, representing the Mesozoic Tethys, which opened from the Middle Jurassic onward (e.g., De Wever and Baumgartner 1995) and (2) the Valais trough, located NW of the Briançonnais peninsula, probably opening from the Late Jurassic - Early Cretaceous onward (e.g., Frisch 1979; Trümpy 1980; Stampfli et al. 1998). Subduction/collision of these ocean basins and intervening microcontinent(s) in response to convergence between Europe and Africa (Adria) resulted in the formation of the Alpine chain, characterized by a high complexity of nappe structures (e.g., Trümpy 1975; Platt 1986; Le Pichon et al. 1988; Schmid et al. 1996a; Escher et al. 1997; Stampfli et al. 1998; Froitzheim 2001). Unraveling the pre-orogenic paleogeography and the complex Alpine tectono-metamorphic processes is a complicated and challenging task. Due to this complexity, a series of different models have been suggested for the evolutionary history of the Alps over the many years of geological research (see e.g., review articles by Escher et al. 1997 or Froitzheim 2001 and references cited therein). Figure 1 shows one of these models with a schematic cross section 
NW

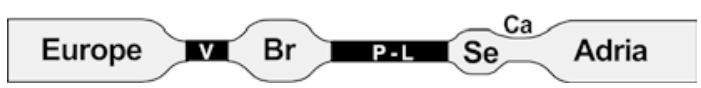

Fig. 1 Schematic profile from the European to the Adriatic plate (NW-SE) representing a model for the pre-orogenic situation in the area of the Central and Western Alps. This model is based on a series of radiometric data (mainly SHRIMP) for both protolith and metamorphic ages (see also text). Gray domains Continental crust; black domains oceanic crust; $V$ Valais basin; $B r$ Briançonnais microcontinent; $P$-L Piemont-Ligurian basin; Se Sesia fragment; $\mathrm{Ca}$ Canavese basin

of the paleogeographical situation in the Western and Central Alps, before the onset of convergence between Africa and Europe. The model is mainly based on a series of geochronological data (see summary by Gebauer 1999). The paleogeographic position, time of formation, and southward subduction of the PiemontLigurian Ocean are generally agreed on in the different

Fig. 2 Map of the Western and Central Alps with the different paleogeographic units, summarizing the radiometric data for the protolith (numbers in regular fonts) and metamorphic ages (numbers in italics) of ophiolitic rocks from the Piemont-Ligurian basin and the Valais basin. Sm-Nd and $\mathrm{Lu}-\mathrm{Hf}$ data are not included in this figure due to their inconsistencies (see text). The map is from Froitzheim et al. (1996). The internal massifs, Dora Maira, Gran Paradiso, and Monte Rosa, are given here as having a European provenance. This is based on a series of radiometric data (see summary by Gebauer 1999) and on a recent tectonic model by Froitzheim (2001). 1 Peters and Stettler (1987); 2 Bill et al. (1997); 3 Rubatto et al. (1998); 4 Liati and Gebauer (2001); 5 Stucki (2001); 6 Costa and Caby (2001); 7 Liati et al. (2002); 8 Schaltegger et al. (2002); 9 Rubatto and Hermann (2003); 10 Liati et al. (2003) models. In contrast, there are controversial views and missing information regarding the Valais Ocean, i.e., its paleogeographic extent, size, age, and duration of spreading, as well as metamorphic age(s) and grade(s). It is generally accepted that, however, the Valais basin was a small ocean SSE of Europe, separated from the main Piemont-Ligurian Ocean by the Briançonnais peninsula. Rifting/spreading processes at the site of future development of the Valais basin probably started in Late Jurassic times (e.g., Schmid et al. 1990; Stampfli et al. 1998 and references therein).

The area studied within the framework of the present paper belongs to the Chiavenna unit, Central Alps (Figs. 2 and 3), classically considered to belong to the Valais Ocean, in the prolongation of the so-called Misox zone (e.g., Schmid et al. 1996b). This zone is undoubtedly considered to contain rocks of the Valais basin (see below). Here we present geochronological data on metabasic rocks from two localities of the Chiavenna unit: (1) close to the town of Chiavenna, and (2) close to the village of Prata (Fig. 3). Our aim was to determine the age of the protolith formation of the amphibolites, as well as their age of metamorphism, because the knowledge of the absolute time of magmatism and metamorphism are very crucial for paleogeographic reconstructions. We applied the $\mathrm{U}-\mathrm{Pb}$ ion microprobe dating (SHRIMP) technique to analyze magmatic and metamorphic zircon domains in sectioned zircon grains. In order to get information about the origin of zircons (e.g., magmatic, metamorphic) and to distinguish between the magmatic and metamorphic domains we used cathodoluminescence imaging of the zircon crystals selected for dating.

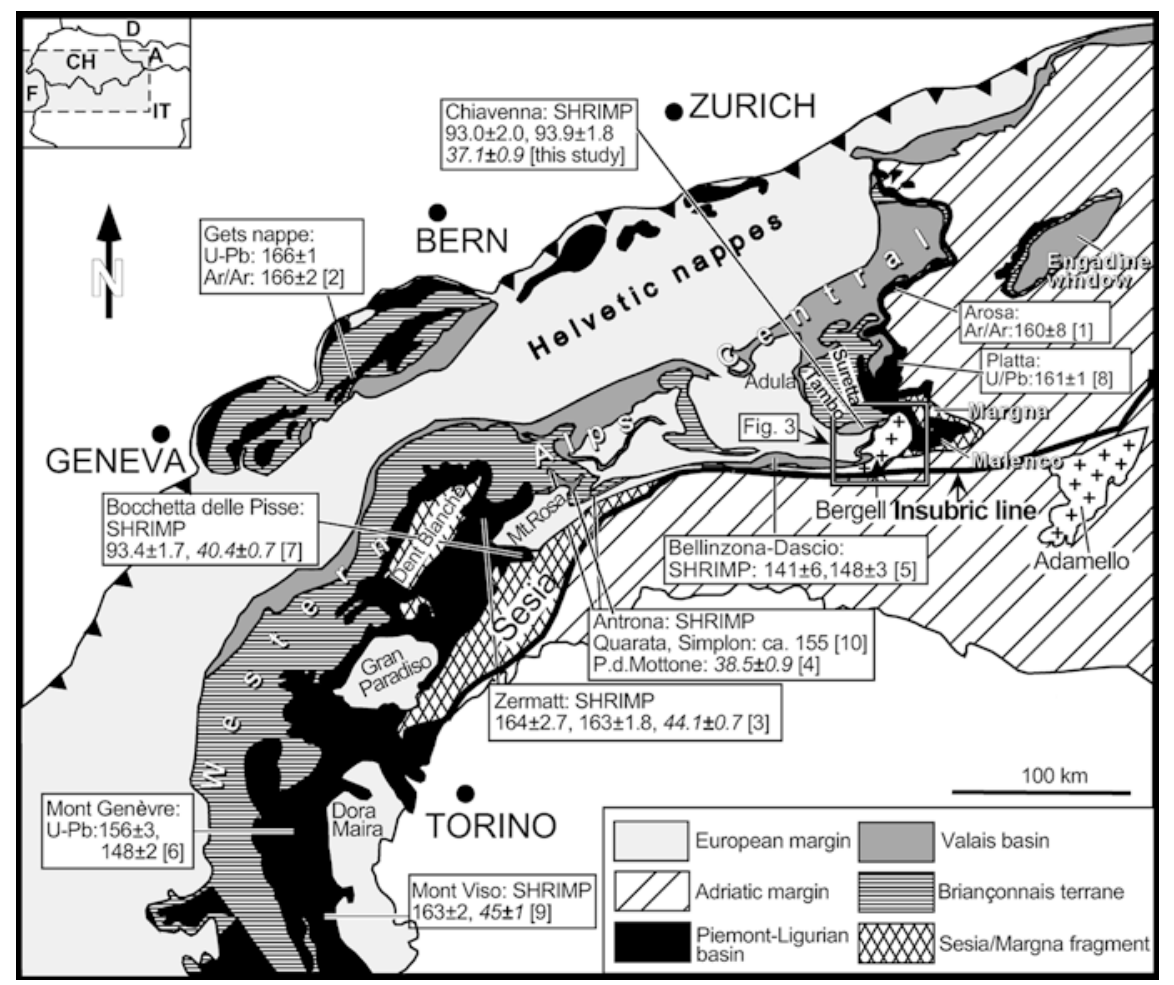


Fig. 3 Tectonic map with the area of the Chiavenna unit, Central Alps, and surrounding tectonic units, showing the locations of the samples dated (map from Schmid et al. 1996a). $F L$ Forcola Line; $I L$ : Insubric Line; PRSZ: Preda Rossa Shear Zone; $M I$ : Misox zone; $B D$ : Bellinzona-Dascio zone; $L M$ : Lago di Mezzola
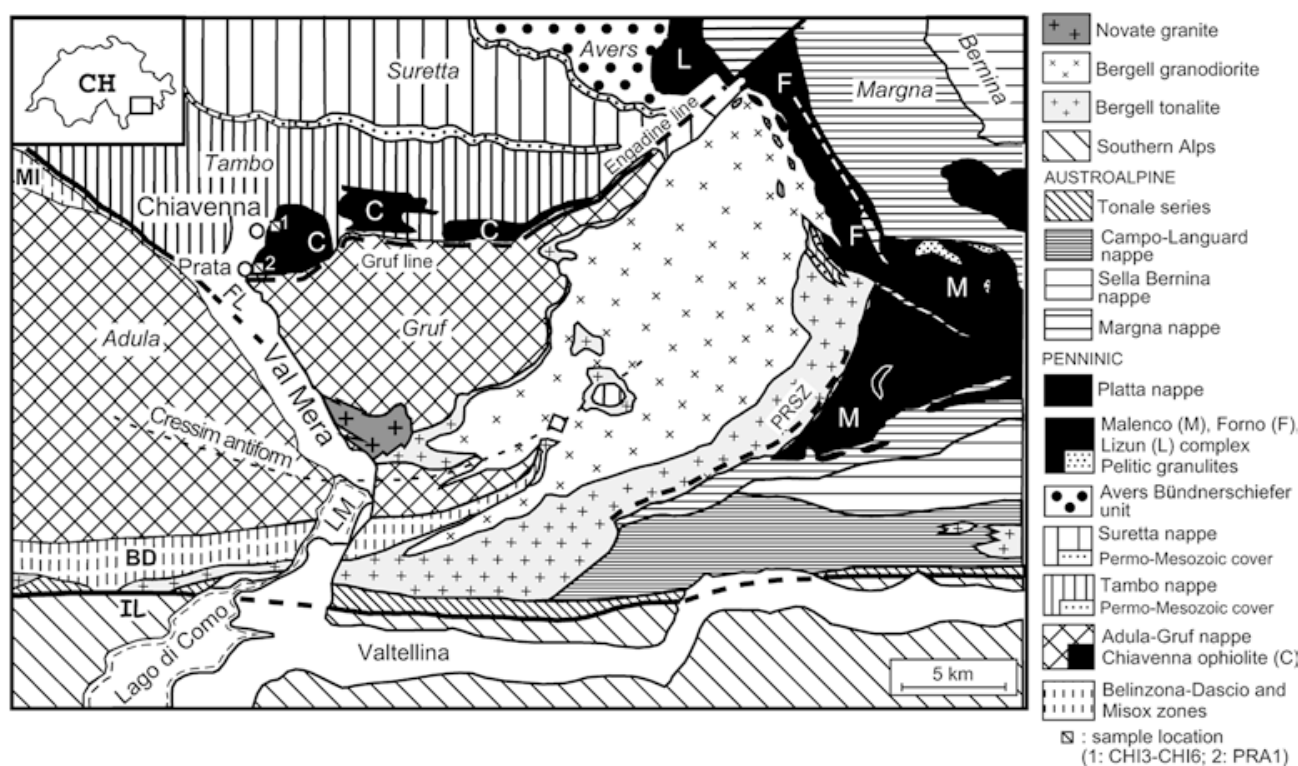

\section{Geological setting}

The Chiavenna unit is situated along the southeastern Swiss-Italian border. It is one of the four Penninic units that form a nappe stack in the Central Alps. These units are, from top to bottom and with increasing metamorphic grade, the Suretta and Tambo nappes, the Chiavenna unit, and the Gruf unit (Fig. 3). The Chiavenna unit consists mainly of metaperidotites, amphibolites, metagabbros, and rare carbonate rocks. It lies tectonically above the Gruf unit to the south and below the Tambo nappe to the north (e.g., Wenk 1955; Froitzheim and Manatchal 1996; Schmid et al. 1996a). The Gruf unit consists of high-grade, upper amphibolite- to granulite-facies metamorphic rocks (migmatitic gneisses, metapelites, amphibolites, and calc-silicate marbles) and is thought to represent the southeastern continuation of the Adula nappe (see e.g., overview papers by Schmid et al. 1996a; Frey and Ferreiro-Mählmann 1999). This view was recently confirmed by geochronological data on felsic granulites from the Gruf unit (Liati and Gebauer 2002), which reveal a metamorphic age at $32.7 \pm 0.5 \mathrm{Ma}$, identical to ages for granulite-facies events of crustal and mantle rocks of the Adula-Cima Lunga nappe system (e.g., Alpe Arami or Cima di Gagnone; Gebauer 1994, 1996). The Tambo nappe, located between the overlying Adula nappe and the underlying Suretta nappe, consists mainly of paragneisses intruded by the Permian Truzzo granite (e.g., Gulson 1973; Marquer et al. 1998). It shows increasing metamorphic grade from middle greenschistfacies in the north to lower-middle amphibolite-facies in the south-southeast.

Generally, the Chiavenna unit and, with less confidence, also the Bellinzona-Dascio zone, which is restricted to the Southern Steep Belt (a zone of steeply north-dipping foliated rocks bounded by the Insubric line at its southern margin; Milnes 1974) have been considered to represent the Valais (north Penninic) suture zone (e.g., Schmid et al. 1996b). The mafic-ultramafic rocks of the Chiavenna unit were interpreted to represent an inverse ophiolite sequence (Schmutz 1974). They have also been considered as an "incomplete" ophiolite sequence, where subcontinental mantle rocks instead of typical oceanic lithosphere are tectonically exposed on an ocean floor and covered by tholeiitic N-type MORBs (Talerico 2001). Similarly, Huber and Marquer (1998) consider the mafic/ultramafic rocks of the Chiavenna unit as subcontinental to oceanic in origin exposed along normal faults on a thinned continental margin.

A progressive metamorphism under PT conditions ranging from $3-4 \mathrm{kbar}, 520^{\circ} \mathrm{C}$ in the north to temperatures up to $700{ }^{\circ} \mathrm{C}$ in the south is suggested by Schmutz (1974). Also, Talerico (2001) suggests a progressive metamorphic evolution at temperature conditions varying between ca. $500{ }^{\circ} \mathrm{C}$ in the northern part and ca. $700{ }^{\circ} \mathrm{C}$ in the southern part of the Chiavenna unit. This latter author distinguishes a dynamic metamorphic event followed by a static thermal overprint related to the emplacement of the hot Gruf unit, which is known to have suffered up to granulite-facies conditions (e.g., summary of Huber and Marquer 1998). It cannot be excluded that the Chiavenna unit has undergone high-pressure metamorphism prior to the amphibolite-facies overprint because of the presence of blueschists and eclogites in the Misox zone (considered as a prolongation of the Chiavenna unit to the north, probably representing the same oceanic suture), which record pressures of ca.11-13 kbar (Oberhänsli 1978; Heinrich 1983; Ring 1992). This possibility is strengthened by our petrographic observations of the amphibolites from the Chiavenna unit (see below, section Description of the samples dated). 


\section{Existing radiometric data on Central and Western Alpine ophiolites}

$\mathrm{U}-\mathrm{Pb}, \mathrm{Sm}-\mathrm{Nd}, \mathrm{Lu}-\mathrm{Hf}$, and $\mathrm{Ar}-\mathrm{Ar}$ radiometric data for the crystallization and metamorphism of ophiolitic rocks are available for several areas of the Western and Central Alps (Fig. 2). Crystallization ages for rocks interpreted to belong to the Piemont-Ligurian Ocean (e.g., Arosa zone, Platta nappe, Zermatt-Saas Fee, Monviso, Gets nappe) range mainly between $148 \pm 2 \mathrm{Ma}$ in the Montgenèvre to $166 \pm 1$ in the Gets Nappe (Peters and Stettler 1987; Bill et al. 1997; Rubatto and Gebauer 1999; Amato et al. 1999; Liati and Gebauer 2001; Costa and Caby 2001; Stucki 2001; Liati et al. 2002; Schaltegger et al. 2002; Rubatto and Hermann 2003; Fig. 2). Radiometric ages of $148 \pm 3$ and $141 \pm 6 \mathrm{Ma}$ (U-Pb on zircon by SHRIMP) from two plagiogranites of the Bellinzona-Dascio zone are attributed to the PiemontLigurian Ocean and were interpreted to represent some of the youngest magmatic activity in this ocean (Stucki 2001). It should be mentioned that, however, the Bellinzona-Dascio zone has been attributed also to the "Valais Ocean and distal European margin" by Schmid et al. (1996b; their Plate 1), on structural grounds. Metamorphic zircon ages (SHRIMP) of $44.1 \pm 0.7$ and $45 \pm 1 \mathrm{Ma}$ are reported for the eclogite-facies metamorphism in the areas of Zermatt and Mont Viso, respectively (Rubatto et al. 1998; Rubatto and Hermann 2003). For Zermatt, distinctly different $\mathrm{Sm}-\mathrm{Nd}$ and $\mathrm{Lu}-$ Hf "ages" of $40.6 \pm 2.6$ and $49.0 \pm 3.3 \mathrm{Ma}$, respectively, have been obtained for identical eclogite samples and, in both cases, interpreted to date UHP-metamorphism (Amato et al. 1999; Lapen et al. 2002). Even significantly different $\mathrm{Sm}-\mathrm{Nd}$ ages were published for different samples of the Zermatt-Saas ophiolites $(49 \pm 4 \mathrm{Ma}$ by Mayer et al. 1999 and $40.6 \pm 2.6 \mathrm{Ma}$ by Amato et al. 1999) and in both cases interpreted to reflect (U)HP metamorphism. Earlier, imprecise $\mathrm{Sm}-\mathrm{Nd}$ mineral data of $52 \pm 18 \mathrm{Ma}$ were published by Bowtell et al. (1994) and were also interpreted to reflect the age of eclogitefacies metamorphism. Similar inconsistencies between and amongst $\mathrm{Sm}-\mathrm{Nd}$ and $\mathrm{Lu}-\mathrm{Hf}$ data on one side and the regionally consistent $\mathrm{U}-\mathrm{Pb}$ SHRIMP data on the other side have been also published for the PiemontLigurian ophiolites of Monviso (49.1 $\pm 1.2 \mathrm{Ma}$ : Lu-Hf by Duchêne et al. 1997 and $60 \pm 12$ Ma, resp. $62 \pm 9$ Ma: Sm-Nd by Cliff et al. 1998 versus $45 \pm 1 \mathrm{Ma}: \mathrm{U}-\mathrm{Pb}$ SHRIMP by Rubatto and Hermann 2003). The scatter of the Sm-Nd- and Lu-Hf-age data may be explained if one considers the problems with complete chemical dissolution of minerals and whole rocks (including spike equilibration) and especially with isotopic disequilibrium between and amongst minerals and mineral inclusions during metamorphism. This applies especially for the common presence of for example pre-metamorphic, i.e., inherited and/or magmatic domains of zircon crystals. Such pre-metamorphic zircon domains carry a major or at least a considerable amount of the whole-rock budget of, mainly, $\mathrm{Hf}$ and/or $\mathrm{Nd}$ that is unlikely to have equilibrated with other minerals during metamorphism(s). Based on the above discussion, we prefer here the SHRIMP data as most reliable, as there is also very good evidence (e.g., high-pressure inclusions) that they reflect (U)HP metamorphism (e.g., Rubatto et al. 1998; Rubatto and Hermann 2003).

Regarding the age of the Valais basin, paleontological data from the sedimentary cover, as well as structural data, suggest that it did not open before Late JurassicEarly Cretaceous times (Frisch 1979; Stampfli 1993; Florineth and Froitzheim 1994; Steinmann 1994). Radiometric data are scarce. Preliminary SHRIMP U-Pb ages on magmatic domains of zircons from an eclogite of the Antrona ophiolites (considered as belonging to the Valais ocean; e.g., Froitzheim 2001) yielded scattered ages, clustering around $133 \mathrm{Ma}$ (Liati and Gebauer 2001). An additional, more complete (SHRIMP) dataset, however, on metabasic rocks from the northernmost, central, and southernmost parts of the Antrona ophiolites show that they are ca. $155 \mathrm{Ma}$ old (Liati et al. 2003; see also summary of radiometric data in Fig. 2). Regarding the metamorphic age of the Antrona ophiolites, SHRIMPdata at $38.5 \pm 0.9$ and $40.4 \pm 0.7 \mathrm{Ma}$ are reported for amphibolitized eclogites in the Passo del Mottone area (Liati and Gebauer 2001) and immediately south of the Monte Rosa nappe (Bocchetta delle Pisse area; Liati et al. 2002; see also below and Fig. 2).

A series of ${ }^{39} \mathrm{Ar} /{ }^{40} \mathrm{Ar}$ amphibole data from various amphibolites of the Chiavenna unit are reported by Talerico (2001): edenite-poor amphiboles interpreted as "index minerals of an Eocene regional medium temperature metamorphism" gave 45-47 Ma. Various Mghornblendes gave an age range of 30-35 Ma interpreted to reflect a nearly static high-temperature thermal overprint "associated with regional thermal changes contemporaneous to the emplacement of the MasinoBregaglia intrusions" (30-32 Ma).

\section{Description of the samples dated}

Five amphibolite samples were collected for dating from the Chiavenna unit, four of them ca. $300 \mathrm{~m}$ ENE of the town center of Chiavenna and one ca. $1.5 \mathrm{~km}$ ESE of Prata, along the Schiesone valley (Fig. 3). The amphibolites sampled close to Chiavenna town are medium to fine grained and show a well expressed orientation of the minerals along the schistosity. The amphibolite collected in the area of Prata is coarse to medium grained and generally does not show a well-expressed mineral orientation. Its macroscopic textural appearance characterizes this rock as a metagabbro (see also Huber and Marquer 1998 and below, section CL patterns and morphology of zircons). Four out of these five amphibolite samples contained zircons.

The petrography and petrology of the Chiavenna unit have been studied in detail (Schmutz 1974; Talerico 2001). The same is true also for the geochemistry 
of basic/ultrabasic rocks of this unit (Dürr et al. 1993; Talerico 2001). A detailed petrological and geochemical study is beyond the scope of this paper. Here, we briefly comment on the petrography of the samples dated by SHRIMP. For comparison with the literature data, we also give whole-rock chemical analyses for major and trace elements of two amphibolite samples, one from Chiavenna and one from Prata (Table 1).

The amphibolites dated from the outcrop close to the town of Chiavenna consist mainly of hornblende and plagioclase. Their common mineral assemblage is hornblende-plagioclase-biotite-zoisite-sphene \pm rutile-quartz \pm apatite-opaques \pm zircon. Fine intergrowths (symplectites) of amphibole + plagioclase

Table 1 Whole-rock analyses of amphibolites from the unit of Chiavenna, close to Ciavenna town (CHI6) and close to Prata (PRA1). $\mathrm{FeO}^{*}$ Total $\mathrm{Fe}$ as $\mathrm{FeO}$

\begin{tabular}{|c|c|c|}
\hline & CHI6 & PRA1 \\
\hline \multicolumn{3}{|l|}{$\mathrm{wt} \%$} \\
\hline $\mathrm{SiO}_{2}$ & 49.11 & 49.12 \\
\hline $\mathrm{TiO}_{2}$ & 1.38 & 1.55 \\
\hline $\mathrm{Al}_{2} \mathrm{O}_{3}$ & 15.96 & 16.65 \\
\hline $\mathrm{FeO}^{*}$ & 9.31 & 10.22 \\
\hline $\mathrm{MnO}$ & 0.18 & 0.17 \\
\hline $\mathrm{MgO}$ & 8.73 & 8.38 \\
\hline $\mathrm{CaO}$ & 10.95 & 9.68 \\
\hline $\mathrm{Na}_{2} \mathrm{O}$ & 2.93 & 3.44 \\
\hline $\mathrm{K}_{2} \mathrm{O}$ & 0.20 & 0.24 \\
\hline $\mathrm{P}_{2} \mathrm{O}_{5}$ & 0.10 & 0.06 \\
\hline $\mathrm{SO}_{3}$ & 0.01 & 0.01 \\
\hline LOI & 0.94 & 1.5 \\
\hline Total & 99.80 & 101.03 \\
\hline M-value & 51 & 48 \\
\hline \multicolumn{3}{|l|}{ (ppm) } \\
\hline $\mathrm{Rb}$ & 8 & 15 \\
\hline $\mathrm{Sr}$ & 152 & 192 \\
\hline $\mathrm{Ba}$ & 46 & 65 \\
\hline $\mathrm{Sc}$ & 31 & 35 \\
\hline Y & 32 & 33 \\
\hline $\mathrm{Zr}$ & 84 & 98 \\
\hline $\mathrm{Nb}$ & 3 & 7 \\
\hline $\mathrm{Cr}$ & 326 & 306 \\
\hline $\mathrm{Ni}$ & 78 & 107 \\
\hline $\mathrm{Co}$ & 69 & 93 \\
\hline $\mathrm{Pb}$ & 3 & 3 \\
\hline V & 256 & 275 \\
\hline $\mathrm{Cu}$ & 25 & 47 \\
\hline $\mathrm{Zn}$ & 78 & 116 \\
\hline $\mathrm{Ga}$ & 16 & 15 \\
\hline As & 4 & 4 \\
\hline Mo & 2 & 2 \\
\hline $\mathrm{Sn}$ & 7 & 17 \\
\hline $\mathrm{La}$ & 5 & 5 \\
\hline $\mathrm{Ce}$ & 6 & 6 \\
\hline $\operatorname{Pr}$ & 3 & 3 \\
\hline $\mathrm{Nd}$ & 3 & 3 \\
\hline $\mathrm{Sm}$ & 3 & 3 \\
\hline $\mathrm{Hf}$ & 2 & 4 \\
\hline $\mathrm{Ta}$ & 2 & 9 \\
\hline W & 191 & 299 \\
\hline $\mathrm{Bi}$ & 3 & 3 \\
\hline $\mathrm{Th}$ & 9 & 3 \\
\hline $\mathrm{U}$ & 2 & 3 \\
\hline
\end{tabular}

were observed inside diablastic hornblende, a characteristic feature commonly found in overprinted HP metabasites. No relics of the pre-existing mineral that gave rise to these symplectites are preserved. Worth mentioning is also the presence of rutile in these amphibolites. Rutile is commonly the Ti phase in highpressure metabasites, according to empirical observations and experimental data (e.g., Hellman and Green 1979), although it may be present also in amphibolites that have not been subjected to high-pressure metamorphism. Although not a proof, the presence of rutile in the dated amphibolites of Chiavenna suggests that they may have seen higher pressure than that indicated by their current mineralogical composition. These observations may be considered as a hint to look in more detail for HP relics in the rocks of the Chiavenna unit, especially considering the fact that its northern prolongation, the Misox zone, contains blueschists and eclogites (Oberhänsli 1978; Heinrich 1983; Ring 1992). It may well be that the Chiavenna unit has been overprinted much stronger than the Misox zone, especially in its southern parts, during the ca. $33 \mathrm{Ma}$ old (Liati and Gebauer 2002) granulite-facies metamorphism of the neighboring Gruf unit, possibly leading to almost complete obliteration of eventual high-pressure minerals and/or mineral textures. In addition, a 24-25 Ma old reheating and fluid event (Gebauer 1996; Liati et al. 2000) triggered by the emplacement of the Novate granite, to the south of the Chiavenna unit, may have contributed to destruction of subduction-related highpressure relics.

Microscopic study of the Prata amphibolite shows that it is a coarse- to medium-grained rock with some leucocratic (plagioclase-rich) parts containing coarser grained hornblende. It consists mainly of hornblende and plagioclase, roughly in equal amounts. Opaque minerals, probably ilmenite \pm magnetite, are abundant. Minor amounts of biotite, quartz, rutile, and zircon are also present.

Chemical analyses of two amphibolites (one close to Chiavenna town and one close to Prata; Fig. 3) are given in Table 1. The Prata amphibolite shows textural characteristics indicative of a gabbroic precursor (see above). The whole-rock analyses of major and trace elements by XRF were performed at the Mineralogy and Petrology Institute, University of Bonn. Both samples show absolute major and trace element abundances closely resembling those of mid-ocean ridge basalts. This is mainly true for the so-called incompatible "immobile" elements, such as $\mathrm{Ti}, \mathrm{P}, \mathrm{Zr}, \mathrm{Y}, \mathrm{Nb}$ (compare with Saunders and Tarney 1984; Hofmann 1988; Sun and McDonough 1989). Previous studies showed that the protoliths of the amphibolites of the Chiavenna unit are tholeiitic in composition with N-type MORB affinities (Dürr et al. 1993; Talerico 2001). The bulk chemistry of the dated samples, therefore, is in agreement with geochemical data reported for this unit in the literature, which indicate an oceanic setting of formation. 


\section{Dating technique and data evaluation}

\section{SHRIMP II}

The age data were obtained on SHRIMP II at the Geological Survey of Canada (GSC) in Ottawa and at the Research School of Earth Sciences (RSES), The Australian National University (ANU), Canberra. The spot size used for analysis was about $20 \mu \mathrm{m}$, with a few exceptions where a ca. $10 \mu \mathrm{m}$ spot was used because of the very small size of some zircon crystals and domains. For data collection, seven scans through the critical mass range were made. $\mathrm{U} / \mathrm{Pb}$ ratios at the GSC were calibrated relative to standard BR266, which is a piece of a Sri Lankan gem-quality zircon (see Stern and Amelin 2003). For the samples analyzed at $\mathrm{ANU}, \mathrm{U} / \mathrm{Pb}$ ratios were calibrated relative to AS3 reference zircon (Paces and Miller 1993), while U and Th concentrations were calculated relative to SL13 (e.g., Compston et al. 1992; Williams 1998).

\section{Cathodoluminescence $(\mathrm{CL})$ imaging}

All CL-pictures were taken from a split screen on a CamScan CS 4 scanning electron microscope (SEM) at ETH in Zürich operating at $13 \mathrm{kV}$. The SEM is equipped with an ellipsoidal mirror that is located close to the sample within the vacuum chamber and that can be adjusted by electro-motors. The sample, thus, can be located in one focal point while the second focal point lies outside the sample chamber. Here, the CL light enters a highly sensitive photo multiplier through a quartz glass-vacuum window and a light channel. The signal of the photo multiplier is then used to produce the CL picture via a video-amplifier. Secondary electron (SE)-pictures were produced simultaneously with the CL pictures using a different detector. In general, weak CL emission (dark colors in the picture) means high amounts of minor and trace elements; strong $\mathrm{CL}$ emission (light colors in the picture) means low amounts of minor and trace elements, including U (e.g., Sommerauer 1974). Thus, the $\mathrm{U}$ contents can be qualitatively predicted via CL.

\section{Data evaluation}

Data were corrected for common $\mathrm{Pb}$ using the ${ }^{204} \mathrm{~Pb}$ ${ }^{207} \mathrm{~Pb}$ and ${ }^{208} \mathrm{~Pb}$ correction method (see Williams 1998). Although the resulting ages are identical within error limits, we finally use the ${ }^{207} \mathrm{~Pb}$ correction for the zircons of young age. Because this correction is based on the assumption of concordance, the data are graphically presented on Tera-Wasserburg (TW) diagrams (Tera and Wasserburg 1972), where total ${ }^{207} \mathrm{~Pb} /{ }^{206} \mathrm{~Pb}$ vs. the calibrated total ${ }^{238} \mathrm{U} /{ }^{206} \mathrm{~Pb}$ is plotted. This diagram has also the advantage of fast estimation of the amount of common lead of the individual analyses, directly from the plot. The amount of common $\mathrm{Pb}$ was calculated using the isotope composition of common $\mathrm{Pb}$ obtained from the model of Cumming and Richards (1975). The ages of the inherited zircons (Paleozoic and older) are given as 204-corrected ${ }^{206} \mathrm{~Pb} /{ }^{238} \mathrm{U}$ ages for analytically concordant data and as 204-corrected ${ }^{207} \mathrm{~Pb} /{ }^{206} \mathrm{~Pb}$ ages for analytically discordant data (Table 2). The ${ }^{207} \mathrm{~Pb} /{ }^{206} \mathrm{~Pb}$ ages are minimum ages for the magmatic formation of these oscillatory zoned domains.

For the weighted mean age calculations, as well as for the diagrams presented in this paper, the Isoplot/Ex computer program (version 2.4) was used (Ludwig
2000). Errors on the weighted mean ages in Table 2, text, and figures are given at the $95 \%$ confidence level. For single analyses (Table 2), $1 \sigma$ errors are given.

\section{CL-patterns and morphology of zircons}

Amphibolites near Chiavenna town (CHI3, CHI4, CHI5, CHI6)

One of the Chiavenna amphibolite samples (CHI5) contained no zircons. In samples $\mathrm{CHI} 3$ and $\mathrm{CHI} 4$, the zircons are small (typically ca. $50 \mu \mathrm{m}$ long and ca. $30 \mu \mathrm{m}$ wide; two grains are a little bigger: ca. $90 \mu \mathrm{m}$ long and ca. $50 \mu \mathrm{m}$ wide). Three grains of sample CHI 4 consist of a single domain with a relatively homogeneous CL pattern, interpreted as entirely metamorphic (Fig. 4C). All other zircon grains are oscillatory zoned, indicating that they precipitated in a melt. These oscillatory zoned zircons proved to be all inherited, as evidenced by the SHRIMP-ages, which were different for each crystal analyzed (see below). This was the case also for sample CHI3. In sample CHI6, the zircon grains are also relatively small, prismatic (80-100 $\mu \mathrm{m}$ long and $60-70 \mu \mathrm{m}$ wide), and more or less euhedral. Two zircon grains of this sample consist, to a large extent, of a single oscillatory zoned domain surrounded at the outermost parts by a very thin (a few micrometers broad) metamorphic rim, bright in CL (e.g., Fig. 4A). One grain consists of an inner (inherited) core surrounded by a relatively broad oscillatory domain of magmatic origin and at the outermost part a very thin CL-bright metamorphic rim (Fig. 4B). The CL oscillatory pattern of the zircons of sample CHI6 is interpreted as co-magmatic. The relatively small size of the zircon crystals can be considered as an indication that the protolith of this amphibolite was rather a sub-volcanic rock or a dyke (e.g., dolerite or fine-grained gabbro) where zircons could not grow large in the relatively rapidly cooling basic melt.

\section{Amphibolite near Prata (metagabbro, PRA1)}

Sixteen zircon crystals were recovered from the amphibolite near Prata. They are relatively large, prismatic (usually between 100 and $350 \mu \mathrm{m}$ long and 50 and $100 \mu \mathrm{m}$ wide), and more or less euhedral. The majority of them consist largely (sometimes almost entirely) of an oscillatory zoned, magmatically formed domain surrounded by a very thin metamorphic rim, bright in CL (Fig. 5A, B). Where this rim gets broader, one can distinguish two rim domains, probably corresponding to different "generations": an inner, CL-brighter and an outer CL-darker rim (e.g., Fig. 5C, upper part of crystal). For a few grains this composite metamorphic rim was broad enough to fit a SHRIMP spot. It was, however, not possible to analyze each individual rim "generation" separately. The crystal size, in combination with the relatively euhedral shape of the zircons, are in 
Table $2 \mathrm{U}$, Th, Pb SHRIMP data for co-magmatic, inherited and metamorphic zircons from the Chiavenna and Prata amphibolites (Chiavenna unit, Central Alps). WM Weighted mean; error on $\mathrm{WM}$ is given at the $95 \%$ confidence level. Uncertainties are given at the $1 \sigma$ level. Analyses in italics are not considered for the WM calculation (see text). For sample PRA1 two weighted mean ages are calculated: one considering analyses $27-32$ and one assuming $\mathrm{Pb}$-loss for analyses $28,30,32$ (see text). The ages for analyses 10 13 are 204 -corrected ${ }^{207} \mathrm{~Pb} /{ }^{206} \mathrm{~Pb}$ ages; those for analyses 9,18 , and 49 are 204-corrected ${ }^{206} \mathrm{~Pb} /{ }^{238} \mathrm{U}$ ages (see text, section Data evaluation). The complete dataset is available by the authors upon request

\begin{tabular}{|c|c|c|c|c|c|c|c|c|}
\hline Sample & $\begin{array}{l}\mathrm{U} \\
(\mathrm{ppm})\end{array}$ & $\begin{array}{l}\text { Th } \\
\text { (ppm) }\end{array}$ & $\mathrm{Th} / \mathrm{U}$ & $\begin{array}{l}\text { rad.Pb } \\
(\mathrm{ppm})\end{array}$ & $\mathrm{f}^{206 \mathrm{a}}$ & $\begin{array}{l}{ }^{238} \mathrm{U} /{ }^{206} \mathrm{~Pb} \\
(1 \sigma) \\
\text { Uncorrected }\end{array}$ & $\begin{array}{l}{ }^{207} \mathrm{~Pb} /{ }^{206} \mathrm{~Pb} \\
(1 \sigma) \\
\text { Uncorrected }\end{array}$ & $\begin{array}{l}\text { Age } \\
(\mathrm{Ma}) \\
{ }^{206} \mathrm{~Pb} /{ }^{238} \mathrm{U}\end{array}$ \\
\hline
\end{tabular}

\section{Chiavenna amphibolites}

\begin{tabular}{llccc}
\multicolumn{7}{l}{ Co-magmatic domains } & & \\
1. & CHI6-4.1 & 872 & 334 & 0.40 \\
2. & CHI6-3.1 & 881 & 257 & 0.30 \\
3. & CHI6-3.2 & 628 & 246 & 0.41 \\
4. & CHI6-2.1 & 781 & 225 & 0.30 \\
5. & CHI6-4.3 & 1263 & 679 & 0.56 \\
6. & CHI6-3.3 & 793 & 113 & 0.15
\end{tabular}

$\begin{array}{ll}13 & 0.01 \\ 12 & 0.04 \\ 10 & 0.02 \\ 11 & 0.0 \\ 21 & 0.00 \\ 9 & 0.23\end{array}$

Inherited domains

\begin{tabular}{|c|c|c|}
\hline & \\
\hline 7. & CHI6-1.1 & 8,080 \\
\hline 8. & CHI6-1.2 & 1,550 \\
\hline 9. & CHI6-4.2 & 454 \\
\hline $10{ }^{\mathrm{b}}$ & CHI3-B1.1 & 2,042 \\
\hline 11 b $^{\mathrm{b}}$ & CHI3-3.1 & 88 \\
\hline $12 .^{\mathrm{b}}$ & CHI3-4.1 & 1,647 \\
\hline $13 .^{\mathrm{b}}$ & CHI3-5.1 & 577 \\
\hline $14 .^{\mathrm{b}}$ & CHI3-2.2 & 800 \\
\hline $15 .^{\mathrm{b}}$ & CHI3-1.1 & 2,333 \\
\hline $16 .^{\mathrm{b}}$ & CHI3-1.2 & 3,860 \\
\hline $17 .^{\mathrm{b}}$ & CHI3-1.3 & 3,828 \\
\hline $18 .^{\mathrm{b}}$ & CHI4-B1.1 & 399 \\
\hline & \multicolumn{2}{|c|}{ Metamorphic domains } \\
\hline 19. & CHI4-1.1A & 30 \\
\hline 20. & CHI4-1.2 & 30 \\
\hline 21. & CHI4-4.1 & 13 \\
\hline 22. & CHI4-4.2 & 24 \\
\hline 23. & CHI4-4.3 & 9 \\
\hline $24 .^{\mathrm{b}}$ & CHI4-1.1 & 34 \\
\hline & CHI4-5.1 & 228 \\
\hline
\end{tabular}

Prata amphibolite

\begin{tabular}{lllll}
\multicolumn{5}{l}{ Co-magmatic domains } \\
26. & PRA1-11.1 & 1,338 & 777 & 0.60 \\
27. & PRA1-8.4 & 1,900 & 2,023 & 1.10 \\
28. & PRA1-8.5 & 447 & 118 & 0.27 \\
29. & PRA1-8.6 & 989 & 391 & 0.41 \\
30. & PRA1-8.1 & 1,093 & 428 & 0.40 \\
31. & PRA1-8.3 & 995 & 356 & 0.37 \\
32. & PRA1-11.2 & 2,597 & 1,834 & 0.73
\end{tabular}

$\begin{array}{lll}1,734 & 0.22 & 304 \\ 316 & 0.21 & 63 \\ 140 & 0.32 & 43 \\ 57 & 0.03 & 200 \\ 66 & 0.75 & \\ 38 & 0.02 & 94 \\ 648 & 1.12 & 34 \\ 647 & 0.81 & \\ 298 & 0.13 & \\ 37 & 0.01 & 82 \\ 32 & 0.01 & \\ 314 & 0.79 & 56 \\ & & \\ 0.3 & 0.01 & 0 \\ 0.4 & 0.02 & 0 \\ 0.1 & 0.01 & 0 \\ 0.4 & 0.02 & 0 \\ 0.1 & 0.01 & 0 \\ 0 & 0.01 & 0 \\ 2 & 0.01 & 1\end{array}$

$\begin{array}{ll}304 & 0.00 \\ 63 & 0.00 \\ 43 & 0.00 \\ 200 & 0.00 \\ 18 & 0.01 \\ 94 & 0.01 \\ 34 & 0.01 \\ 46 & 0.00 \\ 71 & 0.00 \\ 82 & 0.01 \\ 127 & 0.02 \\ 56 & 0.00 \\ & \\ 0 & 0.03 \\ 0 & 0.03 \\ 0 & 0.23 \\ 0 & 0.07 \\ 0 & 0.18 \\ 0 & 0.13 \\ 1 & 0.07\end{array}$

WM of analyses 26-31:91.6 $\pm 2.8 \mathrm{Ma}$; WM excluding analyses $27,29,31,32: 93.9 \pm 1.8 \mathrm{Ma}$ Inherited domains

\begin{tabular}{|c|c|c|c|c|c|c|c|c|c|}
\hline 33. & PRA1-4.1 & 604 & 167 & 0.29 & 26 & 0.01 & $22.91 \pm 0.45$ & $0.0609 \pm 0.0007$ & $272 \pm 5$ \\
\hline 34. & PRA1-5.1 & 346 & 205 & 0.61 & 18 & 0.01 & $21.08 \pm 0.39$ & $0.0623 \pm 0.0018$ & $295 \pm 5$ \\
\hline 35. & PRA1-7A.1 & 283 & 124 & 0.45 & 14 & 0.00 & $21.21 \pm 0.36$ & $0.0540 \pm 0.0008$ & $296 \pm 5$ \\
\hline 36. & PRA1-7B.1 & 575 & 182 & 0.33 & 24 & 0.00 & $23.89 \pm 0.38$ & $0.0536 \pm 0.0003$ & $264 \pm 4$ \\
\hline 37. & PRA1-7C.1 & 164 & 48 & 0.31 & 7 & 0.00 & $22.08 \pm 0.42$ & $0.0530 \pm 0.0008$ & $285 \pm 5$ \\
\hline 38. & PRA1-2.1 & 304 & 75 & 0.26 & 12 & 0.00 & $25.47 \pm 0.41$ & $0.0551 \pm 0.0008$ & $247 \pm 4$ \\
\hline 39. & PRA1-4.2 & 280 & 95 & 0.35 & 10 & 0.00 & $27.77 \pm 0.42$ & $0.0518 \pm 0.0005$ & $228 \pm 3$ \\
\hline 40. & PRA1-5.2 & 279 & 116 & 0.43 & 13 & 0.00 & $21.67 \pm 0.35$ & $0.0520 \pm 0.0004$ & $291 \pm 5$ \\
\hline 41. & PRA1-1A.1 & 2,259 & 520 & 0.24 & 107 & 0.00 & $20.55 \pm 0.36$ & $0.0523 \pm 0.0005$ & $306 \pm 5$ \\
\hline 42. & PRA1-9.1 & 308 & 114 & 0.38 & 12 & 0.03 & $25.67 \pm 0.35$ & $0.0668 \pm 0.0005$ & $242 \pm 3$ \\
\hline 43. & PRA1-3.1 & 338 & 193 & 0.59 & 16 & 0.00 & $23.25 \pm 0.34$ & $0.0544 \pm 0.0006$ & $271 \pm 4$ \\
\hline 44. & PRA1-10.1 & 4,650 & 68 & 0.02 & 171 & 0.00 & $24.61 \pm 0.40$ & $0.0517 \pm 0.0005$ & $257 \pm 4$ \\
\hline 45. & PRA1-12B.1 & 2,000 & 323 & 0.17 & 80 & 0.00 & $23.78 \pm 0.52$ & $0.0515 \pm 0.0009$ & $266 \pm 6$ \\
\hline 46. & PRA1-1B.1 & 276 & 106 & 0.40 & 10 & 0.01 & $26.36 \pm 0.85$ & $0.0556 \pm 0.0017$ & $239 \pm 8$ \\
\hline 47. & PRA1-11.3 & 5,046 & 412 & 0.08 & 191 & 0.00 & $24.53 \pm 0.50$ & $0.0505 \pm 0.0005$ & $258 \pm 5$ \\
\hline 48. & PRA1-11.4 & 2,435 & 109 & 0.05 & 87 & 0.00 & $25.61 \pm 1.86$ & $0.0524 \pm 0.0020$ & $247 \pm 18$ \\
\hline 49. & PRA1-12A.1 & 358 & 366 & 1.06 & 43 & 0.00 & $10.00 \pm 0.40$ & $0.06120 \pm 0.0017$ & $614 \pm 23$ \\
\hline
\end{tabular}

\begin{tabular}{llll}
0.01 & $68.21 \pm 1.37$ & $0.05657 \pm 0.0007$ & $92.8 \pm 1.9$ \\
0.04 & $66.51 \pm 1.39$ & $0.0827 \pm 0.0017$ & $92.0 \pm 1.9$ \\
0.02 & $66.45 \pm 1.46$ & $0.0611 \pm 0.0024$ & $94.7 \pm 2.1$ \\
0.01 & $69.07 \pm 1.62$ & $0.0520 \pm 0.0007$ & $92.2 \pm 2.2$ \\
0.00 & $64.52 \pm 1.49$ & $0.0506 \pm 0.0005$ & $98.83 \pm 2.3$ \\
0.23 & $70.45 \pm 5.83$ & $0.2321 \pm 0.0062$ & $69.7 \pm 5.8$ \\
\multicolumn{4}{l}{} \\
0.00 & WM: $93.0 \pm 2.0 \mathrm{Ma}$ \\
0.00 & $23.66 \pm 1.07$ & $0.0510 \pm 0.0014$ & $247 \pm 10$ \\
0.00 & $10.50 \pm 0.24$ & $0.0531 \pm 0.0007$ & $268 \pm 10$ \\
0.00 & $4.564 \pm 0.049$ & $0.1374 \pm 0.0003$ & $586 \pm 13$ \\
0.01 & $3.067 \pm 0.054$ & $0.1239 \pm 0.0012$ & $2,189 \pm 6$ \\
0.01 & $8.989 \pm 0.118$ & $0.1525 \pm 0.0019$ & $1,987 \pm 19$ \\
0.01 & $11.48 \pm 0.14$ & $0.0628 \pm 0.0008$ & $660 \pm 35 \pm 23$ \\
0.00 & $16.58 \pm 0.23$ & $0.0570 \pm 0.0011$ & $376 \pm 5$ \\
0.00 & $17.11 \pm 0.20$ & $0.0548 \pm 0.0007$ & $366 \pm 4$ \\
0.01 & $23.19 \pm 0.32$ & $0.0526 \pm 0.0003$ & $272 \pm 4$ \\
0.02 & $22.99 \pm 0.30$ & $0.0548 \pm 0.0007$ & $274 \pm 4$ \\
0.00 & $4.931 \pm 0.059$ & $0.0824 \pm 0.0006$ & $1,190 \pm 13$ \\
& \multicolumn{3}{l}{} \\
0.03 & $163.44 \pm 4.59$ & $0.0739 \pm 0.0047$ & $38.1 \pm 1.1$ \\
0.03 & $168.23 \pm 3.97$ & $0.0717 \pm 0.0057$ & $37.1 \pm 0.9$ \\
0.23 & $133.58 \pm 4.09$ & $0.2371 \pm 0.0114$ & $37.3 \pm 1.3$ \\
0.07 & $164.54 \pm 13.94$ & $0.1044 \pm 0.0061$ & $36.4 \pm 3.1$ \\
0.18 & $143.30 \pm 3.59$ & $0.2016 \pm 0.0121$ & $36.7 \pm 1.1$ \\
0.13 & $154.49 \pm 9.03$ & $0.1481 \pm 0.0125$ & $36.3 \pm 2.2$ \\
0.07 & $162.72 \pm 4.96$ & $0.1025 \pm 0.0079$ & $36.7 \pm 1.2$ \\
& WM: $37.1 \pm 0.9 \mathrm{Ma}$ & &
\end{tabular}

WM: $37.1 \pm 0.9 \mathrm{Ma}$

$68.56 \pm 1.01$

$72.88 \pm 1.65$

$67.45 \pm 1.09$

$71.64 \pm 1.23$

$66.76 \pm 1.34$

$70.91 \pm 1.03$

$0.0485 \pm 0.0007$ $0.0498 \pm 0.0004$ $0.0518 \pm 0.0006$ $0.0511 \pm 0.0004$ $0.0592 \pm 0.0012$ $0.0479 \pm 0.0003$ $0.0486 \pm 0.0008$

$93.3 \pm 1.4$ $87.6 \pm 2.0$ $94.4 \pm 1.5$ $89.0 \pm 1.5$ $94.5 \pm 1.9$ $90.3 \pm 1.3$ $86.9 \pm 1.6$ 
Table 2 (Contd.)

\begin{tabular}{|c|c|c|c|c|c|c|c|c|c|}
\hline & Sample & $\begin{array}{l}\mathrm{U} \\
(\mathrm{ppm})\end{array}$ & $\begin{array}{l}\text { Th } \\
\text { (ppm) }\end{array}$ & $\mathrm{Th} / \mathrm{U}$ & $\begin{array}{l}\text { rad.Pb } \\
(\mathrm{ppm})\end{array}$ & $\mathrm{f}^{206 \mathrm{a}}$ & $\begin{array}{l}{ }^{238} \mathrm{U} /{ }^{206} \mathrm{~Pb} \\
(1 \sigma) \\
\text { Uncorrected }\end{array}$ & $\begin{array}{l}{ }^{207} \mathrm{~Pb} /{ }^{206} \mathrm{~Pb} \\
(1 \sigma) \\
\text { Uncorrected }\end{array}$ & $\begin{array}{l}\text { Age } \\
(\mathrm{Ma}) \\
{ }^{206} \mathrm{~Pb} /{ }^{238} \mathrm{U}\end{array}$ \\
\hline & \multicolumn{9}{|c|}{ Metamorphic domains } \\
\hline 50. & PRA1-12A.2 & 807 & 4 & 0.01 & 3 & 0.05 & $187.94 \pm 3.69$ & $0.0636 \pm 0.0009$ & $33.5 \pm 0.7$ \\
\hline 51. & PRA1-9.2 & 576 & 113 & 0.20 & 3 & 0.07 & $198.30 \pm 2.92$ & $0.0951 \pm 0.0020$ & $30.4 \pm 0.5$ \\
\hline 52. & PRA1-3.3 & 108 & 27 & 0.26 & 0 & 0.27 & $189.48 \pm 4.02$ & $0.1794 \pm 0.0091$ & $28.2 \pm 0.7$ \\
\hline 53. & PRA1-3.4 & 155 & 33 & 0.22 & 1 & 0.03 & $197.56 \pm 4.94$ & $0.1628 \pm 0.0065$ & $27.8 \pm 0.7$ \\
\hline
\end{tabular}

${ }^{\mathrm{a}} \mathrm{f}^{206}$ denotes the percentage of ${ }^{206} \mathrm{~Pb}$ that is common $\mathrm{Pb}$.

${ }^{\mathrm{b}}$ Analyses obtained with SHRIMP II at the ANU, Canberra, all others at GSC, Ottawa

line with a gabbroic origin of this rock because such large co-magmatic zircons are very unlikely to grow from rapidly cooling basaltic melts.

\section{SHRIMP results and interpretation}

The SHRIMP results are listed in Table 2.

\section{Amphibolites close to Chiavenna town}

Nine data points were obtained from the four zircon grains of the amphibolite CHI6. Five of them are from the oscillatory zoned, co-magmatic domains, three from inherited domains, and one is a mixed analysis of the narrow, CL-bright metamorphic rim (analysis 6) and the neighboring older core (Fig. 4A). On a Tera-Wasserburg diagram, four analyses from the co-magmatic domains plot along a mixing line with common $\mathrm{Pb}$ and

Fig. 4 Cathodoluminescence $(C L)$ pictures of two co-magmatic zircon crystals (A, B) and one entirely metamorphic zircon crystal (C) from the amphibolites of Chiavenna. As shown in pictures $\mathbf{A}$ and B, zircons consist essentially of magmatic, oscillatory domains. In A, a CL-bright metamorphic rim, getting broader on the middle left side of the crystal, can be seen. The SHRIMP-spot was located on both the metamorphic and the magmatic domain of the crystal and, therefore, yielded a mixed "age" of $69.7 \pm 5.8 \mathrm{Ma}$. In $\mathbf{B}$, the lowermost spot slightly touches an old (Precambrian) inherited core and, therefore, yields a mixed "age" of $98.8 \pm 2.3 \mathrm{Ma}$, which is a little older than the ca. 93-Ma co-magmatic domain calibrated total ${ }^{238} \mathrm{U} /{ }^{206} \mathrm{~Pb}$ as end members (Fig. 6A). They yield a weighted mean ${ }^{206} \mathrm{~Pb} /{ }^{238} \mathrm{U}$ age at $93.0 \pm 2.0 \mathrm{Ma}$ (MSWD: 0.35; error at $95 \%$ c.1.), which is interpreted as the age of crystallization of the magmatic (doleritic?) protolith. Analyses 5 and 6 of Table 2 were not considered for the weighted mean age calculation because, as shown by post-SHRIMP CL studies, the analyzed spot clearly touches two different neighboring domains thereby yielding mixed "ages" (Fig. 4A: leftmost spot; 4B: lowermost spot). Two SHRIMP analyses on another grain yielded ${ }^{238} \mathrm{U} /{ }^{206} \mathrm{~Pb}$ ages of $247 \pm 10$ and $268 \pm 10 \mathrm{Ma}$ (error: $1 \sigma$ ) indicating that this grain is inherited. Finally, the core domain of grain 4 (Table 2, analysis 9) yielded a Precambrian age $(587 \pm 13 \mathrm{Ma}, 1 \sigma)$.

Our attempts to date the protolith age of the amphibolite samples $\mathrm{CHI} 3$ and CHI4 failed: we obtained different (apparent) ages (Proterozoic to Triassic; Table 2) from all zircon grains, which are obviously all inherited. This is an additional indication that the protoliths of these amphibolites were rather subvolcanic rocks or basalts (see also above, section CL patterns and morphology of zircons). The distribution of ages obtained from the inherited zircon grains or domains of the amphibolites near Chiavenna town are shown in the histogram of Fig. 7.

Seven analyses on three different entirely metamorphic zircon grains from sample CHI4 are plotted on the TW diagram of Fig. 6B. The data plot along a mixing line with common $\mathrm{Pb}$ and calibrated total ${ }^{238} \mathrm{U} /{ }^{206} \mathrm{~Pb}$ as end members intersecting the concordia at a weighted mean ${ }^{238} \mathrm{U} /{ }^{206} \mathrm{~Pb}$ age of $37.1 \pm 0.9 \mathrm{Ma}$ (MSWD: 0.21),

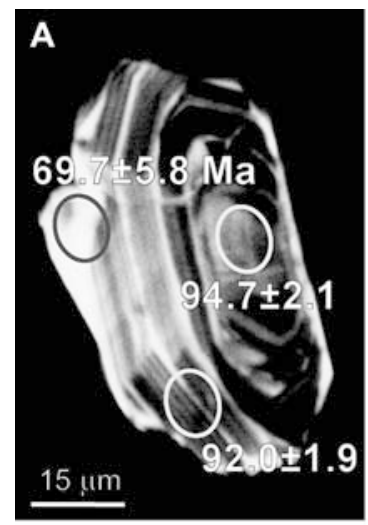

CHI6-3

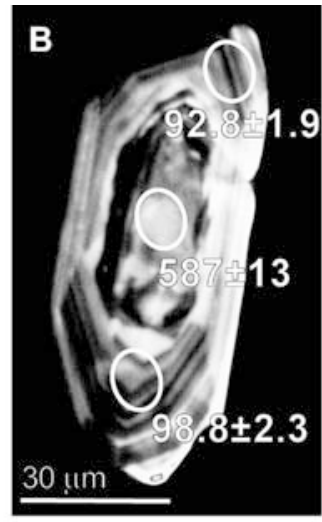

$\mathrm{CHI6-4}$

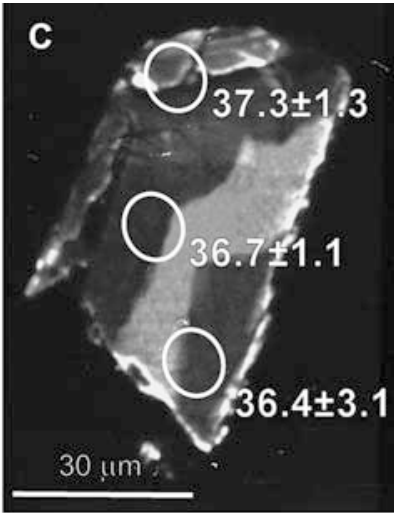

$\mathrm{CH} 44-4$ 


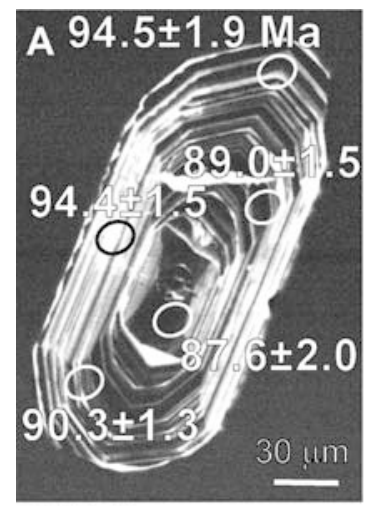

PRA1-8

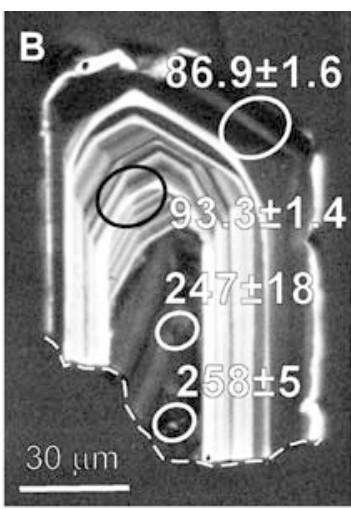

PRA1-11

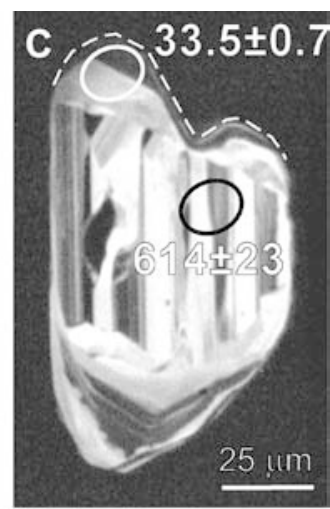

PRA1-12
Fig. 5A-C Cathodoluminescence $(C L)$ pictures of zircon crystals from the metagabbro of Prata (Chiavenna unit). Crystal A consists of an entirely oscillatory domain interpreted as co-magmatic, surrounded by a very thin metamorphic rim, bright in CL. Crystal B consists of an inherited, Permian core surrounded by a comagmatic, Late Cretaceous domain, which is in turn surrounded by a very thin, outermost metamorphic rim, bright in CL. Note that the uppermost right spot age at $86.9 \pm 1.6 \mathrm{Ma}$ is likely to be a result of $\mathrm{Pb}$ loss, probably due to its position at the outermost part of the crystal. Crystal $\mathbf{C}$ consists of an inherited Proterozoic core and a metamorphic rim. Note that the metamorphic rim consists of an inner CL-brighter and an outer CL-darker domain, probably formed during distinct metamorphic/fluid events (see text). The analyzed rim spot lies on both generations of metamorphic domains, thus yielding a mixed metamorphic "age". The dashed line in $\mathbf{B}$ and $\mathbf{C}$ is drawn to outline the crystal limits

interpreted as the age of metamorphism. This age is within error identical to the $38.5 \pm 0.9 \mathrm{Ma}$ age of metamorphism reported for an amphibolitized eclogite of the Antrona ophiolites, at Passo del Mottone (Liati and Gebauer 2001).

Amphibolite close to Prata (metagabbro, PRA1)

Twenty-eight analyses were obtained from 16 different zircon grains recovered from this rock. Seven of them are from the youngest oscillatory zoned, co-magmatic domains. On a TW diagram (Fig. 8), six analyses plot along a mixing line (dashed line) with common $\mathrm{Pb}$ and calibrated total ${ }^{238} \mathrm{U} /{ }^{206} \mathrm{~Pb}$ as end members. One analysis plots on the right side of this mixing line (dashed ellipse), probably due to $\mathrm{Pb}$ loss attributed to subsequent metamorphism(s). The weighted mean age of the six analytically concordant spots is $91.6 \pm 2.8 \mathrm{Ma}$ (error at 95\% c.1.) and has excess scatter (MSWD: 3.1). It is interpreted as the time of crystallization of the gabbroic protolith. This age is identical to that obtained for the formation of the protolith of the amphibolite close to the town of Chiavenna. Although all spots considered here for the weighted mean age calculation overlap within limits of error and fit statistically on a single mixing line (Fig. 8, dashed line), it is possible that three analyses (27, 29, and 31 of Table 2; gray ellipses of Fig. 8) may show minor lead loss during subsequent metamorphism(s). If this is true, the three remaining analyses (the three left-most ellipses in Fig. 8; analyses 26, 28, and 30 of Table 2) yield a weighted mean age at $93.9 \pm 1.8 \mathrm{Ma}$ (with no excess scatter; MSWD: 0.21) instead of the above obtained 91.6 $\pm 2.8 \mathrm{Ma}$. Although
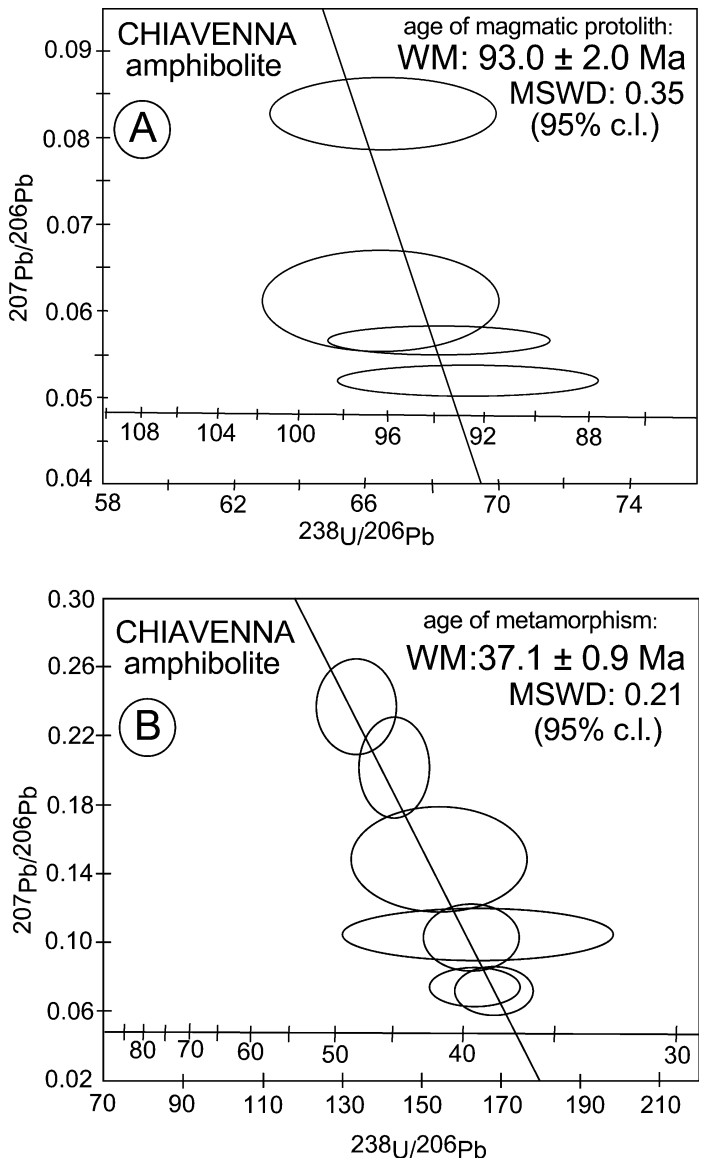

Fig. 6 Tera-Wasserburg diagrams with data of zircons from two amphibolites of Chiavenna. In A four analyses from the comagmatic, oscillatory zoned zircon domains plot along a mixing line with common $\mathrm{Pb}$ (composition from the model of Cumming and Richards 1975) and ${ }^{238} \mathrm{U} /{ }^{206} \mathrm{~Pb}$ as end members, intersecting the concordia curve at $93.0 \pm 2.0 \mathrm{Ma}$. In $\mathbf{B}$ seven analyzed spots from metamorphic domains are plotted. They intersect the concordia curve at $37.1 \pm 0.9 \mathrm{Ma}$, thus indicating a major fluid/ metamorphic event at that time (see text). Errors on the ellipses are $2 \sigma . W M$ Weighted mean; error on the weighted mean is given at the $95 \%$ confidence level 


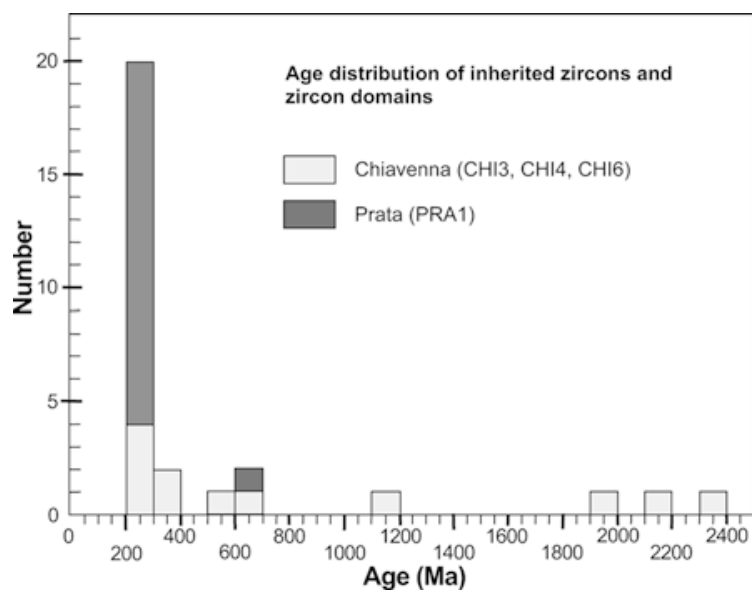

Fig. 7 Age distribution of inherited zircons and zircon domains from the amphibolites of Chiavenna and Prata. A high age concentration is observed between 220 and $300 \mathrm{Ma}$, probably due to mantle melting episodes related to rifting processes at that time (see text)

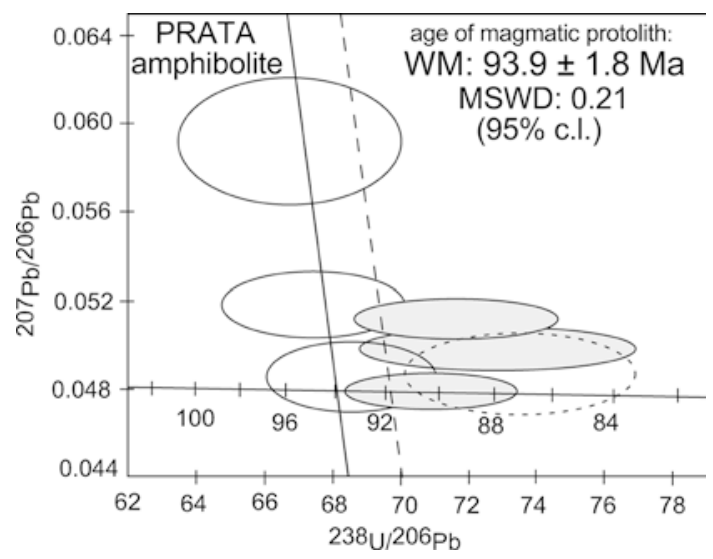

Fig. 8 Tera-Wasserburg diagram with data of zircons from the amphibolite of Prata (metagabbro). Six analyses from the co-magmatic, oscillatory zoned zircon domains plot along a mixing line (dashed line) with common $\mathrm{Pb}$ (composition from the model of Cumming and Richards 1975) and ${ }^{238} \mathrm{U} /{ }^{206} \mathrm{~Pb}$ as end members, intersecting the concordia curve at $91.6 \pm 2.8 \mathrm{Ma}$. One spot (dashed ellipse) plots to the right side of the mixing line, due to $\mathrm{Pb}$ loss. Three spots (gray filled ellipses) may have also suffered $\mathrm{Pb}$ loss. If these three spots are omitted, a more precise weighted mean age of $93.9 \pm 1.8 \mathrm{Ma}$ is obtained (see also text)

both weighted mean ages are identical within error limits, we prefer the higher because of its more precise weighted mean age and because we consider minor $\mathrm{Pb}$ loss as a very likely scenario (see above).

Sixteen analyses from inherited magmatic domains of the Prata amphibolite yielded a few Carboniferous, but mainly Permo-Triassic ages ranging from $306 \pm 5$ to $228 \pm 3 \mathrm{Ma}(1 \sigma$; Table 2; Figs. 7 and 9). These largely Permo-Triassic ages found in the inherited zircons are probably correlated with mantle-melting (metasomatic/ metamorphic) events due to the well known lateand post-Hercynian rifting episodes (see summary by Schaltegger and Gebauer 1999). The Wetherill
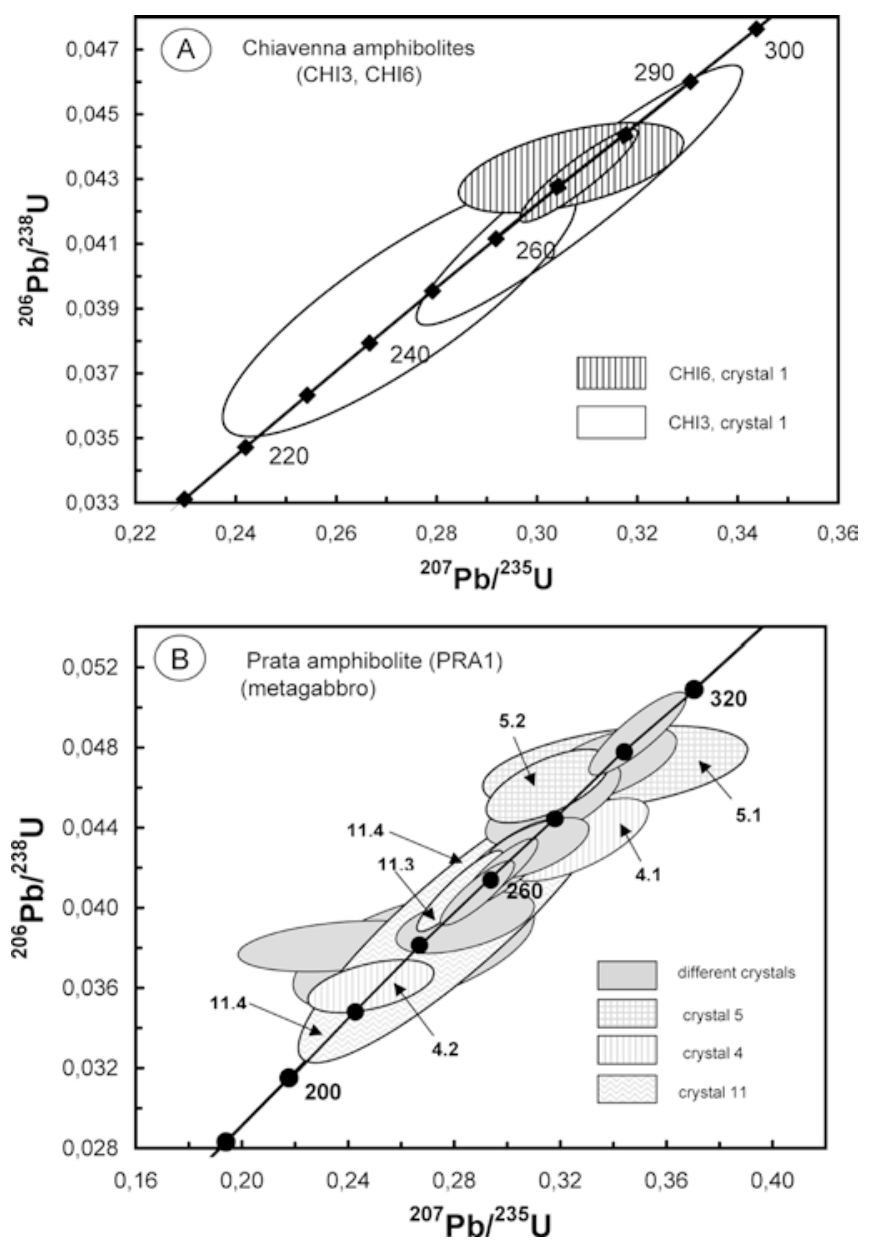

Fig. 9 Concordia diagrams of inherited, mainly Permo-Triassic zircon domains from the amphibolites of Chiavenna A and Prata $\mathbf{B}$ showing possible $\mathrm{Pb}$-loss from ca. 305 down to $228 \mathrm{Ma}$. Both concordant ages (e.g., CHI6: crystal 1, CHI3: crystal 1 in 9A or crystals 5 and 11 in 9B) and discordant ages (crystal 4 in 9B) are identified. Gray ellipses of 9B correspond to analyses on different crystals. They may be related to rifting episodes as young as ca. $230 \mathrm{Ma}$ known from other areas of the Alps (see text)

concordia diagrams of Fig. 9, which include mainly Permo-Triassic and few Upper Carboniferous zircon analyses, show the existence of both concordant (overlapping ellipses referring to analyses on the same zircon grains) and at least partly discordant (not overlapping ellipses) ages in the time range between ca. 305 and ca. $228 \mathrm{Ma}$, for two amphibolites close to the town of Chiavenna (samples CHI3 and CHI6) and one close to Prata (sample PRA1). It is interesting that we have not obtained any (apparent) ages between ca. 230 and ca. $93 \mathrm{Ma}$ from these zircons (Figs. 7 and 9). The lack of data in this time range (230-ca. $93 \mathrm{Ma})$ strengthens the view that the Permo-Triassic ages are related to rifting processes and not to variable $\mathrm{Pb}$ loss during Eocene metamorphism and Oligocene overprinting, in which case one would expect scattering between ca. 230 and ca. $93 \mathrm{Ma}$. Very similar observations have previously been made for zircons from mainly felsic Hercynian rocks of various parts of the Central and Western Alps (e.g., 
summary by Schaltegger and Gebauer 1999). Moreover, the existence of a large number of inherited zircons (Fig. 7) in the amphibolite of Prata and in those of Chiavenna (CHI3, CHI4) strongly favors the proximity of the Chiavenna unit to continental crust. Therefore, an origin of the "ophiolites" from stripped subcontinental mantle sources, rifted in the Permo-Triassic and successively exposed during progressive Mesozoic oceanization, already suggested for certain rocks by Huber and Marquer (1998) and Talerico (2001), is supported by our data mainly on the metagabbro of Prata.

Huber and Marquer (1998), in their paleogeographic interpretation for the Chiavenna unit, suggested that the Chiavenna metagabbros intruded near the mantle-crust boundary before the Mesozoic extension. Our new SHRIMP data on co-magmatic and inherited zircons from both types of amphibolites at Chiavenna and Prata (section Description of the samples dated) partly support this hypothesis: the presence of large amounts of PermoTriassic oscillatory zircons and zircon domains mainly in the metagabbro of Prata indicates partial mantle melting episodes at that time, indirectly implying the presence of gabbroic intrusions near the crust-mantle boundary, associated to Permo-Triassic rifting. However, the assumption of the above authors that the "overlying basalts" are related to the first stages of the Valais Ocean opening is not confirmed by our data. In fact, these finegrained, layered amphibolites, at least for the samples dated, which do not derive from basalts but from intrusive rocks (e.g., dolerites or fine-grained gabbros: sample CHI6 and gabbros: sample PRA1) rather reflect late stages of formation of Valais Oceanic crust. This follows from the presence of co-magmatic ca. $93 \mathrm{Ma}$ old zircons that would not crystallize in rapidly cooled basalts.

As for the age of metamorphism of the Prata metagabbro, it was possible to obtain four analyses from three metamorphic rims due to the very few available metamorphic domains. They yielded Oligocene ages of $28.2 \pm 0.7,27.8 \pm 0.7,33.5 \pm 0.7$, and $30.4 \pm 0.5 \mathrm{Ma}(1 \sigma)$. According to the post-SHRIMP CL study, all spots are located within composite (poly)metamorphic rims consisting of two types of metamorphic domains (a CLdarker and a CL-brighter domain; e.g., Fig. 5C). This indicates that the rock was affected by at least two metamorphic/fluid events at different times. Therefore, the metamorphic ages that we obtained from these composite rims are mixed ages. Although these data cannot provide precisely the time of each metamorphic event or episode, they indicate that the last metamorphic/fluid event should have taken place after $27.8 \pm 0.7 \mathrm{Ma}$, the youngest "age" obtained by the composite metamorphic rims. The most likely age of the post-27.8 Ma metamorphic domains is $24-25 \mathrm{Ma}$, which corresponds to the time of intrusion of the Novate granite (Liati et al. 2000) and to the age of numerous pegmatite dykes in the southern steep belt that caused considerable fluid flow and reheating (e.g., Gebauer 1996). Similarly, the $33.3 \pm 0.7 \mathrm{Ma}$ mixed analysis gives a minimum age for the older metamorphic domain. The most likely age of this metamorphic domain is $37.1 \pm 0.9 \mathrm{Ma}$, the age of the first regional metamorphism of the Chiavenna unit (see above). Of course, a ca. 33 Ma metamorphic event related to the granulite-facies metamorphism in the neighboring Gruf complex may also have played a role for the post-37.1 \pm 0.9 Ma old overprints. Such a scenario may well explain the numerous multigrain ${ }^{39} \mathrm{Ar} /{ }^{40} \mathrm{Ar}$ data of Talerico (2001) obtained from different hornblende mixtures containing hornblende of different chemical compositions. Although there is a concentration of ages of hornblende mixtures in the range 30 to $35 \mathrm{Ma}$, there are also step ages below $30 \mathrm{Ma}$ and a concentration of ages at 45$47 \mathrm{Ma}$. These older ages are not supported by the SHRIMP-data and we interpret them as a result of excess Ar often found in metamorphic terranes, especially in HP rocks (e.g., Kelley et al. 1994). For the data of Talerico (2001) that are below $35 \mathrm{Ma}$, we think that inherited $\mathrm{Ar}$ and/or mixing of different hornblende generations and domains are the most plausible causes for the observed data scatter.

\section{Geodynamic implications and discussion}

The ca. $93 \mathrm{Ma}$ (Late Cretaceous) age obtained for the time of crystallization of the magmatic protoliths of the amphibolites from the Chiavenna unit, Central Alps, record the youngest oceanic magmatism ever reported in the Alps. These amphibolites occur in a unit including abundant mafic/ultramafic rocks with oceanic (MORB) geochemical affinities (Dürr et al. 1993; Talerico 2001), interpreted earlier as remnants of (also) ophiolitic origin (Schmutz 1974; Huber and Marquer 1998; Schmid et al. 1997). In the following, we discuss the different aspects and geodynamic implications resulting from the new protolith and metamorphic ages obtained in this study and compare them with previous age data on oceanic rocks from the North-Penninic, Valais Ocean.

As mentioned in the Introduction several models have been proposed for the paleogeographic reconstruction and geodynamic evolution of the Alps (see e.g., summary by Escher et al. 1997; Froitzheim 2001). Here, we describe briefly the model based mainly on a series of geochronological data obtained over the last ca. 10 years in key areas of the Alps. This model involves generally the existence of successive subduction/collision episodes propagating from SSE to NNW direction (see e.g., Rubatto et al. 1998; Gebauer 1999). The main geotectonic domains involved in this scheme are, from south to north, the Adriatic plate (including the Southern Alps and thinned continental margins, such as the Sesia zone, and the Austroalpine nappes), the PiemontLigurian Ocean, the Briançonnais microcontinent (a peninsula connected to Iberia), the Valais Ocean and, finally, the European plate (Fig. 10). In these different paleogeographic domains, peak metamorphic ages get younger from the SSE to the NNW, i.e. from the Sesia zone in the south (subduction at ca. $65 \mathrm{Ma}$ ) through the 


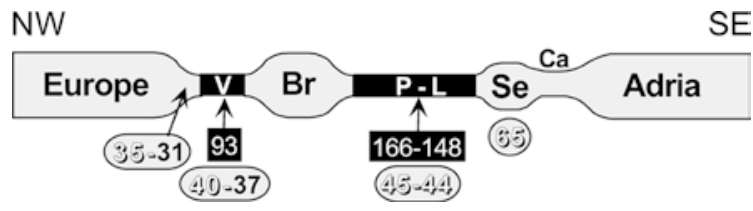

Fig. 10 Schematic profile from the European to the Adriatic plate (NW-SE) representing a model for the pre-orogenic situation in the area of the Central and Western Alps. This model is based on a series of radiometric data (mainly SHRIMP) for both protolith and metamorphic ages. Numbers on black background are protolith ages for ophiolitic rocks. Numbers on gray background are metamorphic ages: numbers in black refer to amphibolite facies ages, those in white refer to HP stages of metamorphism. Radiometric data are as follows: for the European margin they include Alpe Arami (Gebauer 1996), Dora Maira (Gebauer et al. 1997) and Monte Rosa (Rubatto and Gebauer 1999); for the Valais basin they include the Antrona ophiolites, Western Alps (Liati and Gebauer 2001), ophiolites of Valais origin south of the Monte Rosa nappe, Western Alps (Liati et al. 2002) and this study. For localities and references regarding the Piemont-Ligurian Ocean see Fig. 2; for the Sesia zone data are from Rubatto et al. (1999). Gray domains Continental crust; black domains oceanic crust; $V$ Valais basin; $\mathrm{Br}$ Briançonnais microcontinent; $P$ - $L$ Piemont-Ligurian basin; $\mathrm{Se}$ Sesia fragment; $\mathrm{Ca}$ Canavese basin

oceanic Piemont-Ligurian metamorphic rocks (subduction at ca. 44-45 Ma), the oceanic Valais metamorphic rocks (high-pressure and following amphibolite grade metamorphism between ca. 40-37 Ma) to the European margin (high-pressure and subsequent granulite- and amphibolite-grade metamorphism between ca. 35$31 \mathrm{Ma}$; for details and references see Fig. 10 and Gebauer 1999). This model is in agreement with the paleogeographic origin of the above mentioned units, as well as with lithological and structural evidence (e.g., Froitzheim 2001).

The $37.1 \pm 0.9$ Ma metamorphic age obtained for the amphibolites of the Chiavenna unit is within error identical to the $38.5 \pm 0.9 \mathrm{Ma}$ age reported for HPmetamorphism related to subduction of the Valais Ocean (Fig. 2; Antrona ophiolites: area of Passo del Mottone; Liati and Gebauer 2001). Subduction of oceanic crust to (U)HP conditions in the Piemont-Ligurian Ocean is reported at ca. 44-45 Ma (Rubatto et al. 1998; Rubatto and Hermann 2003). Another published Sm-Nd age of 40.6 $\pm 2.6 \mathrm{Ma}$ (Amato et al. 1999) and a $\mathrm{Lu}-\mathrm{Hf}$ age of $49.0 \pm 3.3 \mathrm{Ma}$ (Lapen et al. 2002) are interpreted here to be the result of the lack of isotopic homogenization and/or mixing of real and apparent ages of different mineral components (see also the section Existing radiometric data on Central and Western ophiolites above and Rubatto and Hermann 2003). Therefore, based mainly on its metamorphic age, the Chiavenna unit is considered to be part of the Valais domain, in agreement with previous geological arguments (see the Introduction).

Regarding the age of ca. $93 \mathrm{Ma}$ obtained for the protoliths of two amphibolites of the Chiavenna unit and how this age relates to the time of formation of the Valais oceanic crust, an overview of the literature data reveals the following: opening of the northern part of the
Central Atlantic during the Late Jurassic caused westward drift of Iberia, Sardinia, Corsica and the Briançonnais peninsula relative to the northern Eurasian plate (e.g., Frisch 1979; Stampfli 1993, his Fig. 8 or Rosenbaum et al. 2002). As a result of this westward motion, the Valais Ocean started to open north of the eastwards developing Briançonnais peninsula, at least partly within existing Jurassic Piemont-Ligurian oceanic crust (Stampfli 1993). According to kinematic models by e.g., Srivastava et al. (1990), Malod and Mauffret (1990), Sibuet and Colette (1991), or Gradstein et al. (1994), spreading in the Valais Ocean lasted from the BarremoAptian (beginning of Barremian: ca. $116 \mathrm{Ma}$ ) to the Albo-Cenomanian (end of Cenomanian: ca. $91 \mathrm{Ma}$ ). Thus, the ca. $93 \mathrm{Ma}$ ages obtained for the crystallization time of the mafic protoliths of the Chiavenna unit would represent late stages of spreading in the Valais Ocean.

The abundance of inherited zircons of variable ages (mainly Permo-Triassic, but also Carboniferous, Cambrian, and Proterozoic) within the investigated rocks indicates Late Cretaceous (93 Ma) partial mantle melting within subcontinental mantle or generally MORB-type mantle close to a continental margin. This finding supports further the view that the Chiavenna rocks formed close to a thinned continental crust and, therefore, originated from stripped subcontinental mantle, tectonically exposed during progressive oceanization (compare Huber and Marquer 1998; Talerico 2001).

Of high importance is also the protolith age of $93.4 \pm 1.7 \mathrm{Ma}$ (identical to our $93.0 \pm 2.0$ and 93.9 $\pm 1.8 \mathrm{Ma}$ protolith ages) and HP-metamorphic age of $40.4 \pm 0.7 \mathrm{Ma}$ (comparable to our metamorphic age of $37.1 \pm 0.9 \mathrm{Ma}$ ) reported for an amphibolitized eclogite associated with ultramafic rocks in the Western Alps, at the southern tectonic contact to the Monte Rosa nappe (Bochetta delle Pise area, Fig. 2; Liati et al. 2002). This rock comes from a tectonic unit newly defined on structural grounds (named "Balma unit"; Froitzheim, personal communication), interpreted to belong to the Valais Ocean, based on the paleogeographic reconstruction of Froitzheim (2001). This interpretation is strengthened by the $40.4 \pm 0.7 \mathrm{Ma}$ age of HP-metamorphism of this $93.4 \pm 1.7 \mathrm{Ma}$ old amphibolitized eclogite, which strongly argues for subduction of the Valais, and not of the Piemont-Ligurian oceanic crust, for which peak metamorphic conditions were dated at 44-45 Ma (Rubatto et al. 1998; Rubatto and Hermann 2003). Therefore, the ca. 93 Ma oceanic magmatism is not restricted to the Valais domain in the Central Alps, but is more widespread in the Alpine orogen.

Besides the above mentioned ca. 93 Ma old protolithand ca. 37-40 Ma old metamorphic ages, other recently obtained SHRIMP-data from areas generally accepted to belong to the Valais domain (metabasic rocks from the northernmost, central, and southernmost parts of the Antrona ophiolites; see data summarized in Fig. 2) yielded amphibolite protolith ages at ca. $155 \mathrm{Ma}$ (Liati et al. 2003). These ca. $155 \mathrm{Ma}$ ages are in contradiction 
with a ca. 116-91 Ma old Valais basin (lithostratigraphic age; Stampfli et al. 1998) and rather fit with the age of Piemont-Ligurian crust (165-148 Ma). On the other hand, the subduction age of the Antrona ophiolites is ca. $38 \mathrm{Ma}$ (Liati and Gebauer 2001), which does not fit to the age of subduction of the Piemont-Ligurian oceanic crust (44-45 Ma). This apparent contradiction could be solved if we invoke the existence of Valais oceanic crust inside Piemont-Ligurian oceanic crust, as suggested earlier by Stampfli (1993). Such a scenario can explain the presence of oceanic crust of Piemont-Ligurian age present in a paleogeographic position occupied by the Valais domain, as it is likely to be the case for the Antrona ophiolites described above.

\section{Conclusions}

1. The Late Cretaceous crystallization ages $(93.0 \pm 2.0$ and $93.9 \pm 1.8 \mathrm{Ma}$ ) of the magmatic protoliths of the amphibolites from the Chiavenna unit (Central Alps) are the first record of the youngest oceanic basic magmatism in the Alps.

2. Metamorphism of the Chiavenna unit took place at $37.1 \pm 0.9 \mathrm{Ma}$, which is identical, within errors, to the $38.5 \pm 0.9 \mathrm{Ma}$ age of HP-metamorphism of an amphibolitized eclogite from the Antrona ophiolites (Liati and Gebauer 2001). The new $37.1 \pm 0.9 \mathrm{Ma}$ age of metamorphism for the Chiavenna unit (generally accepted to belong to the Valais domain) strongly argues that also the Antrona ophiolites belong paleogeographically and tectonically to the Valais domain. Thus, the new data for metamorphism (ca. 37-40 Ma) and oceanic magmatism (ca. $93 \mathrm{Ma}$ ) of the Valais domain, together with the Piemont-Ligurian protolith age of ca. $155 \mathrm{Ma}$ of the Antrona ophiolites (Liati et al. 2003) imply that Valais oceanic crust must have formed during Upper Cretaceous times, at least partly, within existing Jurassic Piemont-Ligurian oceanic crust, as assumed earlier by Stampfli (1993). Both oceanic crusts in this part of the Valais domain must have been then subducted and metamorphosed between ca. 40-37 Ma.

3. The Chiavenna unit is confirmed to be attributed to the Valais Ocean situated between the European and the Briançonnais continental crust. Geochronologically, this is based on the protolith ages (ca. $93 \mathrm{Ma}$ ) and especially on the age of metamorphism (ca. $37 \mathrm{Ma}$ ) of the amphibolites. This metamorphism is older than metamorphism of the European margin (Adula-Gruf nappe) to the north, subducted and metamorphosed under eclogite- and amphibolite-facies conditions between 35-31 Ma. It is younger than metamorphism of the Briançonnais microcontinent to the south, which probably occurred between ca. 44 and $40 \mathrm{Ma}$ and also younger than (U)HP metamorphism of the Piemont-Ligurian oceanic crust at 44-45 Ma (see Fig. 10). The new ages confirm the model of stepwise younger metamorphic ages from the SSE to the NNW (Fig. 10), which is thought to be due to successive subduction/collision stages in the area of the Central and Western Alps.

4. The presence of abundant inherited zircons and zircon domains (Late Hercynian, Hercynian, Caledonian, Pan-African, and Proterozoic) in the ca. $93 \mathrm{Ma}$ old protoliths of the Chiavenna amphibolites (Fig. 7) clearly indicates the proximity of the Chiavenna unit to a thinned continental crust. It is also in line with the Late Cretaceous (93 Ma) partial mantle melting related to the formation of the gabbroic and doleritic protoliths of the Chiavenna amphibolites occurring in the subcontinental mantle. Thus, the view that the Chiavenna unit originates from stripped subcontinental mantle tectonically exposed during progressive oceanization (Huber and Marquer 1998; Talerico 2001) is in tune with our data.

Acknowledgements We very much appreciate the help of $M$. Hamilton and R.A. Stern during various stages of the SHRIMP work. R. Huber is thanked for her help in part of the field work and for discussions. W. Wittwer is cordially thanked for zircon separation. Numerous fruitful discussions with N. Froitzheim, Bonn, as well as his help with the geochemical analyses are greatly appreciated. Constructive comments by V. Trommsdorff, Zürich, on an early draft of the manuscript, as well as by W. Frisch, Tübingen and A. Möller, Potsdam, who reviewed this paper, are gratefully acknowledged. Many thanks also to W. Schreyer, Bochum, for the editorial support. This study was supported by a grant of the Swiss National Science Foundation (20-52662.99).

\section{References}

Amato JM, Johnson CM, Baumgartner LP, Beard BL (1999) Rapid exhumation of the Zermatt-Saas ophiolite deduced from high-precision $\mathrm{Sm}-\mathrm{Nd}$ and $\mathrm{Rb}-\mathrm{Sr}$ geochronology. Earth Planet Sci Lett 171:425-438.

Bill M, Bussy F, Cosca M, Masson H, Hunziker JC (1997) Highprecision $\mathrm{U}-\mathrm{Pb}$ and ${ }^{40} \mathrm{Ar} /{ }^{39} \mathrm{Ar}$ dating of the Alpine ophiolite (Gets nappe, French Alps). Eclogae Geol Helv 90:43-54

Bowtell SA, Cliff RA, Barnicoat AC (1994) Sm-Nd isotopic evidence on the age of eclogitisation in the Zermatt-Saas ophiolite. J Metamorph Geol 12:187-196

Cliff RA, Barnicoat AC, Inger S (1998) Early Tertiary eclogitefacies metamorphism in the Monviso ophiolite. J Metamorph Geol 16:447-455

Compston W, Williams IS, Kirschvink JL, Zichao Z, Guogan M (1992) Zircon U-Pb ages for the Early Cambrian time-scale. J Geol Soc Lond 149:171-184

Costa S, Caby R (2001) Evolution of the Ligurian Tethys in the Western Alps: $\mathrm{Sm} / \mathrm{Nd}$ and $\mathrm{U} / \mathrm{Pb}$ geochronology and rare-earth element geochemistry of the Montgenèvre ophiolite (France). Chem Geol 175:449-466

Cumming GL, Richards GR (1975) Ore lead isotope ratios in a continuously changing Earth. Earth Planet Sci Lett 28:155171

De Wever P, Baumgartner PO (1995) Radiolarians from the base of the Supra-ophiolitic Schistes Lustrés Formation in the Alps (Saint-Véran, France and Traversiera Massif, Italy). In: Baumgartner PO, O'Dogerthy L, Gorican S, Urquhart E, Pillevuit A, De Wever P (eds) Middle Jurassic to Lower Cretaceous Radiolaria of Tethys: occurrences, systematics, biochronology. Mém Géol (Lausanne) 23:725-730 
Duchêne S, Blichert-Toft J, Luais B, Télouk P, Lardeuaux JM, Albarède F (1997) The Lu-Hf dating of garnets and the ages of the Alpine high-pressure metamorphism. Nature 387:586589

Dürr SB, Ring U, Frisch W (1993) Geochemistry and geodynamic significance of Northern Penninic ophiolites from the Central Alps. Schweiz Mineral Petrogr Mitt 73:407-419

Escher A, Hunziker J-C, Marthaler M, Mason H, Sartori M, Stech (1997) A geologic framework and structural evolution of the western Swiss-Italian Alps, in: Pfiffner OA, Lehner P, Heitzmann PZ, Mueler S, Steck A (eds) Deep structure of the Swiss Alps: results of NRP 20, Birkhäuser, Basel, pp 205-221

Florineth D, Froitzheim N (1994) Transition from continental to oceanic basement in the Tasna nappe (Engadine window, Graubünden, Switzerland): evidence for Early Cretaceous opening of the Valais Ocean. Schweiz Mineral Petrogr Mitt 74:134-137

Frey M, Ferreiro-Mählmann R (1999) Alpine metamorphism of the Central Alps. Schweiz Mineral Petrogr Mitt 79:135-154

Frisch W (1979) Tectonic progradation and plate tectonic evolution of the Alps. Tectonophysics 60:121-139

Froitzheim N (2001) Origin of the Monte Rosa nappe in the Pennine Alps: a new working hypothesis. Geol Soc Am Bull 113:604-614

Froitzheim N, Manatschal G (1996) Kinematics of Jurassic rifting, mantle exhumation, and passive-margin formation in the Austroalpine and Penninic nappes (eastern Switzerland). Geol Soc Am Bull 108:1120-1133

Froitzheim N, Schmid S, Frey M (1996) Mesozoic paleogeography and the timing of eclogite-facies metamorphism in the Alps: a working hypothesis. Eclogae Geol Helv 89:81-110

Gebauer D (1994) A P-T-t path for some high-pressure ultramafic/ mafic rock associations and their felsic country-rocks based on SHRIMP-dating of magmatic and metamorphic zircon domains. Example: Central Swiss Alps. Extended abstract version for 16th general meeting of IMA, Pisa, Italy, 4-9 Sept, Abstr Vol, pp 139-140

Gebauer D (1996) A P-T-t path for an (ultra?-) high-pressure ultramafic/mafic rock association and its country rocks based on SHRIMP-dating of magmatic and metamorphic zircon domains. Example: Alpe Arami (Central Swiss Alps). In: Earth processes: reading the isotopic code. Geophys Monogr 95:107111

Gebauer D (1999) Alpine geochronology of the Central and Western Alps: new constraints for a complex geodynamic evolution. Schweiz Mineral Petrogr Mitt 79:191-208

Gebauer D, Schertl H-P, Brix M, Schreyer W (1997) 35 Ma old ultrahigh-pressure metamorphism and evidence for very rapid exhumation in the Dora Maira Massif, Western Alps. Lithos 41:35-24

Gradstein FM, Agterberg FP, Ogg JG, Hardenbol S, Vanveen P, Thierry J, Huang ZH (1994) A Mesozoic time-scale. J Geophys Res Solid Earth 99(B12):24051-24074

Gulson BL (1973) Age relations in the Bergell region of the SouthEast Swiss Alps: with some geochemical comparisons. Eclogae Geol Helv 66:293-313

Heinrich CA (1983) Die regionale Hochdruckmetamorphose der Aduladecke, Zentralalpen, Schweiz. Dissertation, ETH Zürich, No 7282

Hellman PL, Green TH (1979) The role of sphene as an accessory phase in the high pressure partial melting of hydrous mafic compositions. Earth Planet Sci Lett 42:191-201

Hofmann AW (1988) Chemical differentiation of the Earth: the relationship between mantle, continental crust, and oceanic crust. Earth Planet Sci Lett 90:297-314

Huber RK, Marquer D (1998) The tectonometamorphic history of the peridotitic Chiavenna unit from Mesozoic to Tertiary tectonics: a restoration controlled by melt polarity indicators (Eastern Swiss Alps). Tectonophysics 296:205-223

Kelley SP, Arnaud NO, Okay AI, (1994) Anomalously old Ar-Ar ages in high pressure metamorphic terrains. Mineral Mag 58A:468-469
Lapen TJ, Mahlen NJ, Johnson CM, Beard BL, Baumgartner LP (2002) Lu-Hf geochronology of UHP metamorphism in the Zermatt-Saas ophiolite, Lago de Cignana, Italy. Abstracts of the 12th Annual Goldschmidt Conference. Geochim Cosmochim Acta 66:A431

Le Pichon X, Bergerat F, Roulet M-J (1988) Plate kinematics and tectonics leading to the Alpine belt formation; a new analysis. In: Clark SP, Burchfiel BC, Suppe J (eds) Processes in continental lithospheric deformation. Geol Soc Am Spec Paper 218:111-131

Liati A, Gebauer D (2001) U-Pb SHRIMP-dating of zircon domains from eclogites of Antrona (Western Alps): evidence for a Valais Ocean origin. EUG 11. J Conf Abstr 6:600

Liati A, Gebauer D (2002) The Gruf Complex (Central Alps) as part of the Adula nappe: geochronological evidence and geodynamic significance. Eur J Mineral 14(1):101

Liati A, Gebauer D, Fanning M (2000) U-Pb SHRIMP dating of zircon from the Novate granite (Bergell, Central Alps): evidence for Oligocene-Miocene magmatism, Jurassic/Cretaceous continental rifting and opening of the Valais trough. Schweiz Mineral Petrogr Mitt 80:305-316

Liati A, Gebauer D, Froitzheim N (2002) Late Cretaceous basic oceanic magmatism in the Valais ocean, Western and Central Alps: geochronological evidence and paleogeographic implications. Annual Meeting of the Swiss Academy of Natural Sciences, Davos, Abstr vol 1:26

Liati A, Gebauer D, Froitzheim N, Fanning M (2003) Origin and Geodynamic significance of metabasic rocks from the Antrona ophiolites (Western Alps): new insights from SHRIMP-dating. EUG12. J Conf Abstr EAE03-A-12648

Ludwig K (2000) User's manual for Isoplot/Ex, version 2.4. A geochronological toolkit for Microsoft Excel. Berkeley Geochronological Center, Spec Publ no 1a

Malod JA, Mauffret (1990) A Iberian plate motion during the Mesozoic. Tectonophysics 184:261-278

Marquer D, Challandes N, Schaltegger U (1998) Early Permian granitoid magmatism in Brianconnais terranes: Truzzo granite and Roffna rhyolite (Eastern Penninic nappes, Swiss and Italian Alps). Schweiz Mineral Petrogr Mitt 78:397-414

Mayer A, Abouchami W, Dal Piaz DV (1999) Eocene Sm-Nd age for the eclogitic metamorphism of the Zermatt-Saas ophiolite in Ayas valley, Western Alps. Eur Union Geosci 10 Abstr Vol 809

Milnes AG (1974) Structure of the Pennine Zone (Central Alps): a new working hypothesis. Geol Soc Am Bull 85:1727-1732

Oberhänsli R (1978) Chemische Untersuchungen an Glaukophanführenden basischen Gesteinen aus den Bündnerschiefern Graubündens. Schweiz Mineral Petrogr Mitt 58:139-156

Paces JB, Miller JD (1993) Precise U-Pb ages of Duluth Complex and related mafic intrusions, northeastern Minnesota: geochronological insights to physical, petrogenetic, paleomagnetic, and tectonomagmatic process associated with the 1.1 Ga Midcontinent Rift System. J Geophys Res 98:1399714013

Peters T, Stettler A (1987) Radiometric age, thermobarometry and mode of emplacement of the Totalp peridotite in the Eastern Swiss Alps. Schweiz Mineral Petrogr Mitt 67:285-294

Platt JP (1986) Dynamics of orogenic wedges and the uplift of high-pressure metamorphic rocks. Geol Soc Am Bull 97:10371053

Ring U (1992) The Alpine geodynamic evolution of Penninic nappes in the eastern Central Alps: geothermobarometric and kinematic data. J Metamorph Geol 10:33-53

Rosenbaum G, Lister GS, Duboz C (2002) Relative motions of Africa, Iberia and Europe during Alpine orogeny. Tectonophysics 359:117-129

Rubatto D, Gebauer D (1999) Eo/Oligocene (35 Ma) high-pressure metamorphism in the Gornergrat Zone (Monte Rosa, Western Alps): implications for paleogeography. Schweiz Mineral Petrogr Mitt 79:353-362

Rubatto D, Hermann J (2003) Zircon formation during fluid circulation in eclogites (Monviso, Western Alps): implication for 
$\mathrm{Zr}$ and $\mathrm{Hf}$ budget in subduction zones. Geochim Cosmochim Acta (in press)

Rubatto D, Gebauer D, Fanning M (1998) Jurassic formation and Eocene subduction of the Zermatt-Saas Fee ophiolites: implications for the geodynamic evolution of the Central and Western Alps. Contrib Mineral Petrol 132:269-287

Rubatto D, Gebauer D, Compagnoni R (1999) Dating of eclogitefacies zircons: the age of Alpine metamorphism in the Sesia-Lanzo Zone (Western Alps). Earth Planet Sci Lett 167:141-158

Saunders AD, Tarney J (1984) Geochemical characteristics of basaltic volcanism within back-arc basins. In: Kokelaar BP, Howells MF (eds) Marginal basin geology. Spec Publ Geol Soc Lond 16:59-76

Schaltegger U, Gebauer D (1999) Pre-Alpine geochronology of the Central, Western and Southern Alps. Schweiz Mineral Petrogr Mitt 79:79-88

Schaltegger U, Desmurs L, Mantschal G, Müntener O, Meier M, Frank M, Bernoulli D (2002) The transition from rifting to seafloor spreading within a magma-poor rifted margin: field and isotopic constraints. Terra Nova 14:156-162

Schmid SM, Rück P, Schreurs G (1990) The significance of the Schams nappes for the reconstruction of the paleotectonic and orogenic evolution of he Penninic zone along the NFP 20-East traverse (Grisons, Eastern Switzerland). Mem Soc Geol Suisse 1:263-287

Schmid SM, Berger A, Davidson C, Gieré R, Hermann J, Nievergelt P, Pusching R, Rosenberg C (1996a) The Bergell pluton (Southern Switzerland, Northern Italy): overview accompanying a geological-tectonic map of the intrusion and surrounding country rocks. Schweiz Mineral Petrogr Mitt 76:329-355

Schmid SM, Pfiffner OA, Froitzheim N, Schönborn G, Kissling E (1996b) Geophysical-geological transect and tectonic evolution of the Swiss-Italian Alps. Tectonics 15:1036-1064

Schmid SM, Pfiffner OA, Schreurs G (1997) Rifting and collision in the Penninic zone of eastern Switzerland. In: Pfiffner OA, Lehner P, Heitzmann PZ, Mueler S, Steck A (eds) Deep structure of the Swiss Alps: results of NRP 20. Birkhäuser, Basel, pp 160-185

Schmutz HU (1974) Der mafitit-Ultramafitit-Komplex zwischen Chiavenna und Val Bondasca (Prov. Sondrio, Italien; Kt. Graubünden, Schweiz). Dissertation, ETH Zürich, No 5231

Sibuet JC, Colette BJ (1991) Triple junctions of Bay of Biscay and North Atlantic. New constraints on the kinematic evolution. Geology 19:522-525
Sommerauer J (1974) Trace elements distribution patterns and mineralogical stability of zircons: an application for combined electron microprobe techniques. Electron Microsc Soc S Afr Proc 4:71-72

Srivastava SP, Roest WR, Kovacs LC, Oakay G, Levesque S, Verhoef J, Macnab R (1990) Motion of Iberia since the Late Jurassic. Results from detailed aeromagnetic measurements in Newfoundland Basin. Tectonophysics 184:229-260

Stampfli GM (1993) Le Briançonnais, terrain exotique dans les Alpes? Eclogae Geol Helv 86:1-45

Stampfli GM, Mosar J, Marquer D, Marchant R, Baudin T, Borel $\mathrm{G}$ (1998) Subduction and obduction processes in the Swiss Alps. Tectonophysics 296:159-204

Steinmann M (1994) Die Nordpenninischen Bündnerschiefer der Zentralalpen Graubündens: Tektonik, Stratigraphie und Beckenentwicklung. Dissertation, ETH Zürich, No 10668

Stern RA, Amelin Y (2003) Assessment of errors in SIMS zircon $\mathrm{U}-\mathrm{Pb}$ geochronology using a natural zircon standard and NIST SRM 610 glass. Chem Geol 1-32

Stucki A (2001) High grade Mesozoic ophiolites of the Southern Steep Belt, Central Alps. Dissertation, ETH Zürich, No 14206

Sun S, McDonough WF (1989) Chemical and isotopic systematics of oceanic basalts: implications for mantle composition and processes. In: Saunders AD, Norry MJ (eds) Magmatism in the ocean basins. Spec Publ Geol Soc Lond 42:313-345

Talerico C (2001) Petrological and chemical investigation of a metamorphosed oceanic crust-mantle section (Chiavenna, Bergell Alps). Dissertation, ETH Zürich, No 13934

Tera F, Wasserburg GJ (1972) U-Th-Pb systematics in three Apollo 14 basalts and the problem of initial $\mathrm{Pb}$ in lunar rocks. Earth Planet Sci Lett 14:281-304

Trümpy R (1975) Penninic-Austroalpine boundary in the Swiss Alps: a presumed former continental margin and its problems. Am J Sci 275:209-238

Trümpy R (1980) Geology of Switzerland, a guide book. Part A: an outline of the geology of Switzerland. Scweiz Geol Komm, Wepf, Basel

Wenk E (1955) Eine Strukturkarte der Tessiner Alpen. Schweiz Mineral Petrogr Mitt 35:139-152

Williams IS (1998) U-Th-Pb Geochronology by ion microprobe. In: McKibben MA, Shanks WC III, Ridley WI (eds) Applications of microanalytical techniques to understanding mineralizing processes. Rev Econ Geol 7:1-35 